Article

\title{
Urban Aerosol Particle Size Characterization in Eastern Mediterranean Conditions
}

\author{
Tareq Hussein $^{1,2, *}$, Lubna Dada ${ }^{2} \oplus$, Simo Hakala ${ }^{2} \oplus$, Tuukka Petäjä ${ }^{2}$ and Markku Kulmala ${ }^{2}$ \\ 1 Department of Physics, The University of Jordan, Amman 11942, Jordan \\ 2 Institute for Atmospheric and Earth System Research (INAR), University of Helsinki, PL 64, FI-00014 UHEL \\ Helsinki, Finland; lubna.dada@helsinki.fi (L.D.); simo.hakala@helsinki.fi (S.H.); \\ tuukka.petaja@helsinki.fi (T.P.); markku.kulmala@helsinki.fi (M.K.) \\ * Correspondence: tareq.hussein@helsinki.fi
}

Received: 13 October 2019; Accepted: 10 November 2019; Published: 14 November 2019

check for updates

\begin{abstract}
Characterization of urban particle number size distribution (PNSD) has been rarely reported/performed in the Middle East. Therefore, we aimed at characterizing the PNSD (0.01-10 $\mu \mathrm{m})$ in Amman as an example for an urban Middle Eastern environment. The daily mean submicron particle number concentration $\left(P N_{S u b}\right)$ was $6.5 \times 10^{3}-7.7 \times 10^{4} \mathrm{~cm}^{-3}$ and the monthly mean coarse mode particle number concentration $\left(P N_{\text {Coarse }}\right)$ was $0.9-3.8 \mathrm{~cm}^{-3}$ and both had distinguished seasonal variation. The $P N_{S u b}$ also had a clear diurnal and weekly cycle with higher concentrations on workdays (Sunday-Thursday; over $3.3 \times 10^{4} \mathrm{~cm}^{-3}$ ) than on weekends (below $2.7 \times 10^{4} \mathrm{~cm}^{-3}$ ). The $P N_{\text {Sub }}$ constitute of $93 \%$ ultrafine fraction (diameter $<100 \mathrm{~nm}$ ). The mean particle number size distributions was characterized with four well-separated submicron modes $\left(D_{p g, I}, N_{i}\right)$ : nucleation $\left(22 \mathrm{~nm}, 9.4 \times 10^{3} \mathrm{~cm}^{-3}\right)$, Aitken $\left(62 \mathrm{~nm}, 3.9 \times 10^{3} \mathrm{~cm}^{-3}\right)$, accumulation $\left(225 \mathrm{~nm}, 158 \mathrm{~cm}^{-3}\right)$, and coarse $\left(2.23 \mu \mathrm{m}, 1.2 \mathrm{~cm}^{-3}\right)$ in addition to a mode with small geometric mean diameter (GMD) that represented the early stage of new particle formation (NPF) events. The wind speed and temperature had major impacts on the concentrations. The $P N_{\text {Coarse }}$ had a U-shape with respect to wind speed and $P N_{S u b}$ decreased with wind speed. The effect of temperature and relative humidity was complex and require further investigations.
\end{abstract}

Keywords: submicron; coarse; modal structure; meteorological effect; particle number size distribution; seasonal; diurnal

\section{Introduction}

Atmospheric aerosol particles have gained increased attention during recent years due to their effects on the climate and human health [1,2]. While most health studies related to air pollution focus on the mass accumulation of particulate matter (PM), advanced studies have shown the importance of the number size distribution on health. For instance, it has been evident that fine particles are capable of penetrating through the respiratory system and circulating in the bloodstream causing serious health effects in different organs in the human body [3]. While the smallest particles do not contribute significantly to the total measured mass concentration, they constitute the highest fraction of the number concentration of measured particles in various locations, which can be more than 100,000 particles $/ \mathrm{cm}^{3}$. Besides that, governmental policies tend to enforce strategies that eradicate the total mass in an attempt of improving visibility and saving human health; at the same time ignoring the effects of the ultrafine particles (UFP, diameter $<0.1 \mu \mathrm{m}$ ), which have rather complex sources and atmospheric processes. For example, fine and UFP are capable of growing to reach sizes where they constitute a fraction of cloud condensation nuclei $(\mathrm{CCN})$; and thus, indirectly affecting the climate $[4,5]$. 
The drivers behind aerosol particles vary between natural and anthropogenic as well as primary and secondary. Primary particles are emitted to the atmosphere as particles while secondary particles form in the atmosphere via gas-to-particle transformation, which has been known as new particle formation (NPF) observed in various environments and contributing to a major fraction of the total particle number budget [6-8]. Indeed, the complexity of urban aerosols lies in the fact that several sources can contribute in the same particle size range, making it difficult to entangle $[9,10]$. Although, some studies focusing on the particle number size distribution have been conducted around the East Mediterranean region at both urban and remote sites [11-14], very few studies can be found regarding the Middle East [15-21]. In fact, the Middle East and North Africa (MENA) is of extreme interest as it serves as a compilation of aerosol particle sources including natural dust, anthropogenic pollution from petrochemical industry and urbanization, as well as new particle formation.

The aim of this paper is to characterize the aerosol particle number size distribution and explore the drivers behind diurnal and seasonal variability of the number concentrations in Amman, which is an example of Middle Eastern urban conditions. Here we utilized a long-term measurement of particle number size distributions over a wide particle diameter range $(0.01-10 \mu \mathrm{m})$. We also applied modal structure analysis for the population of aerosols by using the multi-lognormal distribution function. We additionally investigated the effect of local meteorology on the aerosol concentrations.

\section{Materials and Methods}

\subsection{Aerosol Measurements}

The long-term aerosol measurement was performed during 1 August 2016-31 July 2017 at the Aerosol Laboratory, which was located on the third floor of the Department of Physics, University of Jordan. The University of Jordan campus was located at an urban background in the north part of Amman, Jordan (Supplementary Material Figure S1). The aerosol measurement consisted of total number concentration and particle number size distribution, described in more detail in the following section.

The particle number size distribution was measured with a scanning mobility particle sizer (NanoScan SMPS 3910, TSI, Minnesota, U.S.) and an optical particle sizer (OPS 3330, TSI, Minnesota, U.S.). Using the NanoScan SMPS (electrical equivalent mobility diameter: 0.01-0.42 $\mu \mathrm{m}, 13$ channels at dry conditions) and the OPS (optical diameter: $0.3-10 \mu \mathrm{m}, 13$ channels at dry conditions) can provide a useful setup to monitor a wide particle diameter range $0.01-10 \mu \mathrm{m}$. However, combining the measurement results of these two instruments is challenging as will be pointed out in the next section.

The NanoScan SMPS consists of four main built-in components: (1) a cyclone inlet to remove large particles, (2) unipolar particle charger, (3) a radial differential mobility analyzer (RDMA), and (4) an isopropanol-based condensation particle counter (CPC). The particle number size distribution scan was $60 \mathrm{~s}$ ( $45 \mathrm{~s}$ upscan and $15 \mathrm{~s}$ downscan). The inlet flow rate was $0.75 \mathrm{lpm}( \pm 20 \%)$ whereas the sample flow rate was $0.25 \mathrm{lpm}( \pm 10 \%)$.

The OPS measured the particle number size distribution using the TSI default particle size bins, which consisted of 13 equally sized bins based on a lognormal scale. The dead-time correction was applied in the OPS operation. Sampling time-resolution was $5 \mathrm{~min}$ with a flow rate $\sim 1 \mathrm{lpm}$.

The total number concentration of submicron aerosols was measured with a portable condensation particle counter (CPC 3007-2, TSI, Minnesota, U.S.). The cutoff size of this CPC was $10 \mathrm{~nm}$ and it was capable of measuring submicron particle number concentration of aerosols with diameters up to $2 \mu \mathrm{m}$. According to the specifications provided by the manufacturer, the maximum detectable concentration was $10^{5} \mathrm{~cm}^{-3}$ with $20 \%$ accuracy. The sampling flow rate was $0.1 \mathrm{lpm}$ (inlet flow rate $0.7 \mathrm{lpm}$ ).

Each instrument had its own aerosol sampling inlet ( 1-m-long and $8 \mathrm{~mm}$ inner diameter) which was led through the wall to sample the outdoor aerosols. Each inlet consisted of short Tygon tubes (4 $\mathrm{mm}$ inner diameter) connected to a diffusion drier (TSI model 3062-NC). The diffusion drier was used to remove the excess moisture from the aerosol sample. 
The aerosol transport efficiency through the aerosol inlet assembly was determined experimentally: ambient aerosol sampling alternatively with and without inlet. The aerosol data was corrected accordingly (Figure S2). The penetration efficiency was $\sim 47 \%$ for $10 \mathrm{~nm}, \sim 93 \%$ for $0.3 \mu \mathrm{m}$, and $\sim 40 \%$ for $10 \mu \mathrm{m}$ particles. Accordingly, the particle number size distributions were corrected for losses in the tubing and the diffusion drier.

Based on the hourly mean total number concentrations, the ratio between SMPS (10-420 nm) and the CPC was approximately 0.86 and the relationship between them was linear with an $\mathrm{R}^{2}=$ 0.78 (Figure S3a). The differences can arise from the fact that the CPC measured the full range of the submicron particles (from $10 \mathrm{~nm}$ up to a couple of micrometers) whereas the SMPS measurement range was nominally within the diameter range 10-420 $\mathrm{nm}$. In practice, the NanoScan was not able to measure aerosols with diameters larger than $250 \mathrm{~nm}$, which makes it an ultrafine $\left(D_{p}<0.1 \mu \mathrm{m}\right)$ particle sizer. On the other hand, considering the number concentration within the diameter range $10-1000 \mathrm{~nm}$, which can be obtained by the combined distributions measured with the SMPS and the OPS, revealed that its mean ratio compared to that measured with the CPC was about 1.14 and the relationship between them was linear with an $\mathrm{R}^{2}=0.78$ (Figure S3b). This is expected because the CPC data was not corrected for sampling line losses.

\subsection{Data Handling}

The measurement time-resolution of the SMPS and the CPC was 1 min and of the OPS was $5 \mathrm{~min}$. In order to construct a wide range of the measured particle number size distribution, we performed the following steps: (1) calculated the 5-min average of the SMPS data, (2) omitted the last two channels in the SMPS (i.e., remaining diameter range was 0.01-0.25 $\mu \mathrm{m}$ ), (3) omitted the first channel in the OPS (i.e., remaining diameter range was $0.32-10 \mu \mathrm{m}$ ), and (4) merged the two distributions. As such, we obtained a combined particle number size distribution covering the diameter range 0.01-10 $\mu \mathrm{m}$.

We calculated the particle number concentration $\left(\mathrm{cm}^{-3}\right)$ within four particle diameter ranges (size-fractionated number concentration): 0.01-0.025 $\mu \mathrm{m}$ (nucleation), 0.025-0.1 $\mu \mathrm{m}$ (Aitken), $0.1-1 \mu \mathrm{m}$ (accumulation), and 1-10 $\mu \mathrm{m}$ (coarse). Consequently, the total number concentration was obtained as the sum of all these fractions. The size-fractionated number concentrations were obtained by integrating (practically summation) the measured particle number size distribution over the specified particle diameter range

$$
P N_{D_{P 2}-D_{P 1}}=\int_{D_{P 1}}^{D_{P 2}} n_{N}^{0} d \log _{10}\left(D_{p}\right),
$$

where $n_{N}{ }^{0}=d N / d \log _{10}\left(D_{p}\right)$ is the measured particle number size distribution and $D_{p}$ is the particle diameter.

The processed aerosol data (including all size-fractionated data) was then converted to hourly statistical analysis. This hourly averaged data was then used to calculate the daily and monthly statistical values. The statistical analysis included average, standard deviation, median, minimum, maximum, and percentiles ( $5 \%, 25 \%, 75 \%$, and $95 \%)$ of valid number of data points, and percentage of valid data points.

\subsection{Multi-Lognormal Distribution}

A particle number size distribution can be characterized with a multi-lognormal distribution function [22]

$$
\sum_{i=1}^{n} \frac{N_{i}}{\sqrt{2 \pi} \log \left(\sigma_{g, i}\right)} \exp \left[-\frac{\left(\log \left(D_{p}\right)-\log \left(D_{p g, i}\right)\right)^{2}}{2 \log ^{2}\left(\sigma_{g, i}\right)}\right]
$$


where $n$ is the number of individual log-normal modes and $D_{p}$ is the aerosol particle diameter, and the three log-normal parameters that characterize an individual log-normal mode $i$ are the mode number concentration $N_{i}$, the geometric variance $\sigma_{g, i}^{2}$, and the geometric mean diameter $D_{p g, i}$.

Here we used the DO-FIT algorithm to fit the particle number size distribution. The original DO-FIT algorithm was developed for the submicron particle size fraction [22]; here it was modified to include the coarse mode fraction. We ran the DO-FIT algorithm to fit the particle number size distributions (0.01-10 $\mu \mathrm{m}, 5$-min resolution) by using a fixed number of modes, which was four.

\subsection{Weather Conditions}

The weather conditions were obtained from the continuous measurement performed on the rooftop of the Department of Physics. In this study, we selected weather data for the same time period as the aerosol measurement (i.e., 1 August 2016-31 July 2017; Figure 1).
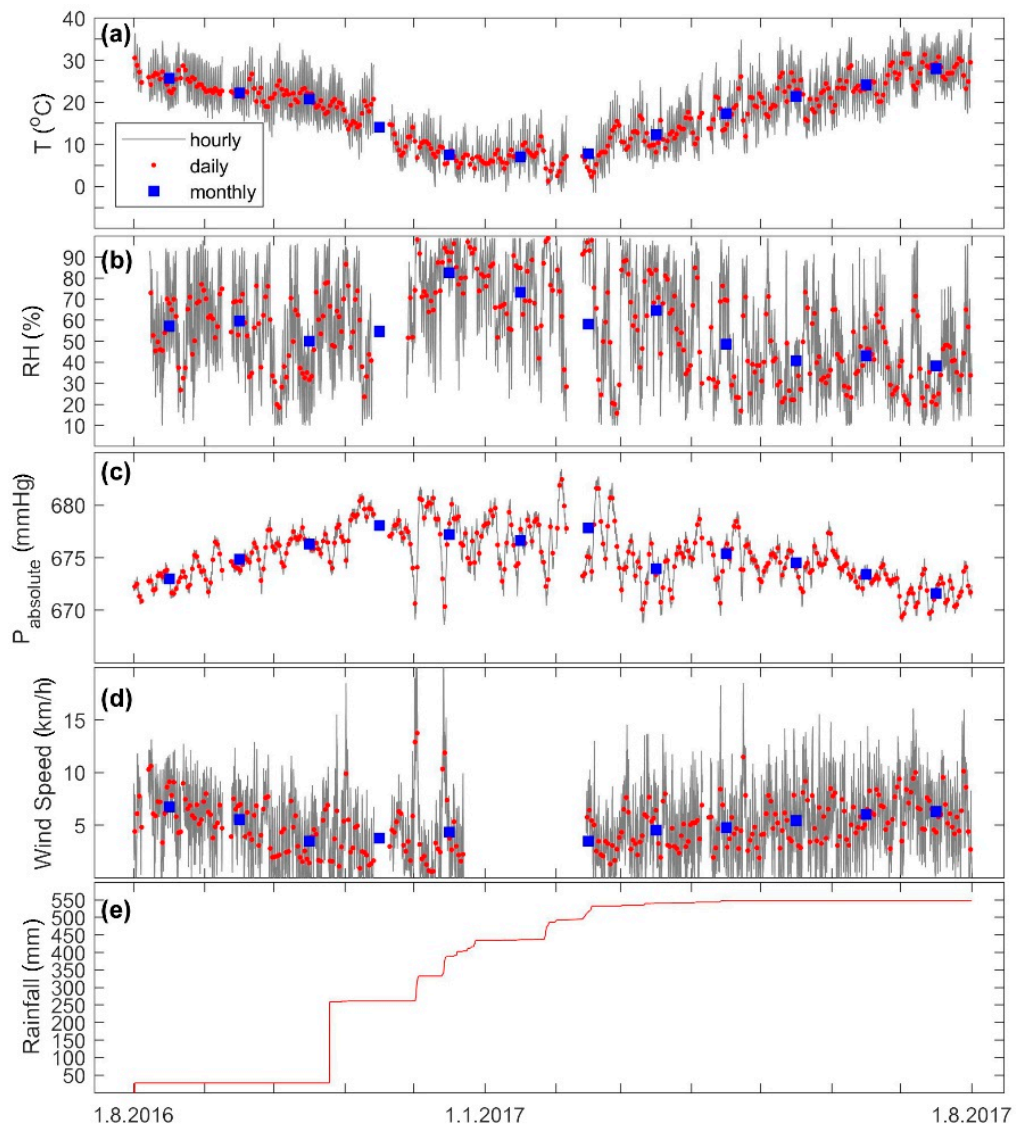

Figure 1. Time series of weather conditions during the measurement period (1 August 2016-31 July 2017) presented as hourly, daily, and monthly means for (a) ambient temperature, (b) relative humidity, (c) absolute pressure, and (d) wind speed. (e) The rainfall is presented as hourly cumulative precipitation.

The weather measurement was performed with a weather station (WH-1080, Clas Ohlson: Art.no. 36-3242). The time resolution of the measurement was $5 \mathrm{~min}$. The weather data consisted of ambient temperature $\left(-40-65^{\circ} \mathrm{C}\right.$, resolution $\left.0.1^{\circ} \mathrm{C}\right)$, absolute pressure $(918.7-1079.9 \mathrm{hPa}$, resolution $0.3 \mathrm{hPa})$, relative humidity $(10 \%-99 \%$, resolution $1 \%)$, wind speed $(1-160 \mathrm{~km} / \mathrm{h})$ and direction (divided into 16 wind sectors), and precipitation (0-9999 mm, resolution $0.3 \mathrm{~mm}$ below $1000 \mathrm{~mm}$ and $1 \mathrm{~mm}$ over $1000 \mathrm{~mm})$.

According to the daily mean (Figure 1 ), the temperature was $1-32{ }^{\circ} \mathrm{C}$ (overall mean $18 \pm 8{ }^{\circ} \mathrm{C}$ ) and the absolute pressure was $670-682 \mathrm{mmHg}$ (overall mean $675 \pm 3 \mathrm{mmHg}$ ). The overall average 
relative humidity was $53 \pm 21 \%$ and the mean wind speed was $5 \pm 3 \mathrm{~km} / \mathrm{h}$. The cumulative rain was about $550 \mathrm{~mm}$.

\section{Results and Discussion}

\subsection{Temporal Variation of the Particle Number Concentrations}

The submicron particle number concentration $\left(P N_{S u b}\right)$ was higher during the winter than during the summer (Figure 2a), suggesting a seasonal variation of fine aerosol number concentrations. Based on the monthly means, $P N_{S u b}$ was in the range $3.3 \times 10^{4}-3.7 \times 10^{4} \mathrm{~cm}^{-3}$ during the winter (December-February) and $1.2 \times 10^{4}-1.6 \times 10^{4} \mathrm{~cm}^{-3}$ during the summer and early autumn (June-September) (Table S1). According to the 24-h mean number concentrations, $P N_{S u b}$ was as high as $6.5 \times 10^{4} \mathrm{~cm}^{-3}$ and as low as $7.7 \times 10^{3} \mathrm{~cm}^{-3}$. According to the hourly means, it was in the range $2.2 \times 10^{3}-2.1 \times 10^{5} \mathrm{~cm}^{-3}$. This seasonal variation was also confirmed by the CPC observations (Figure $2 b$ ).
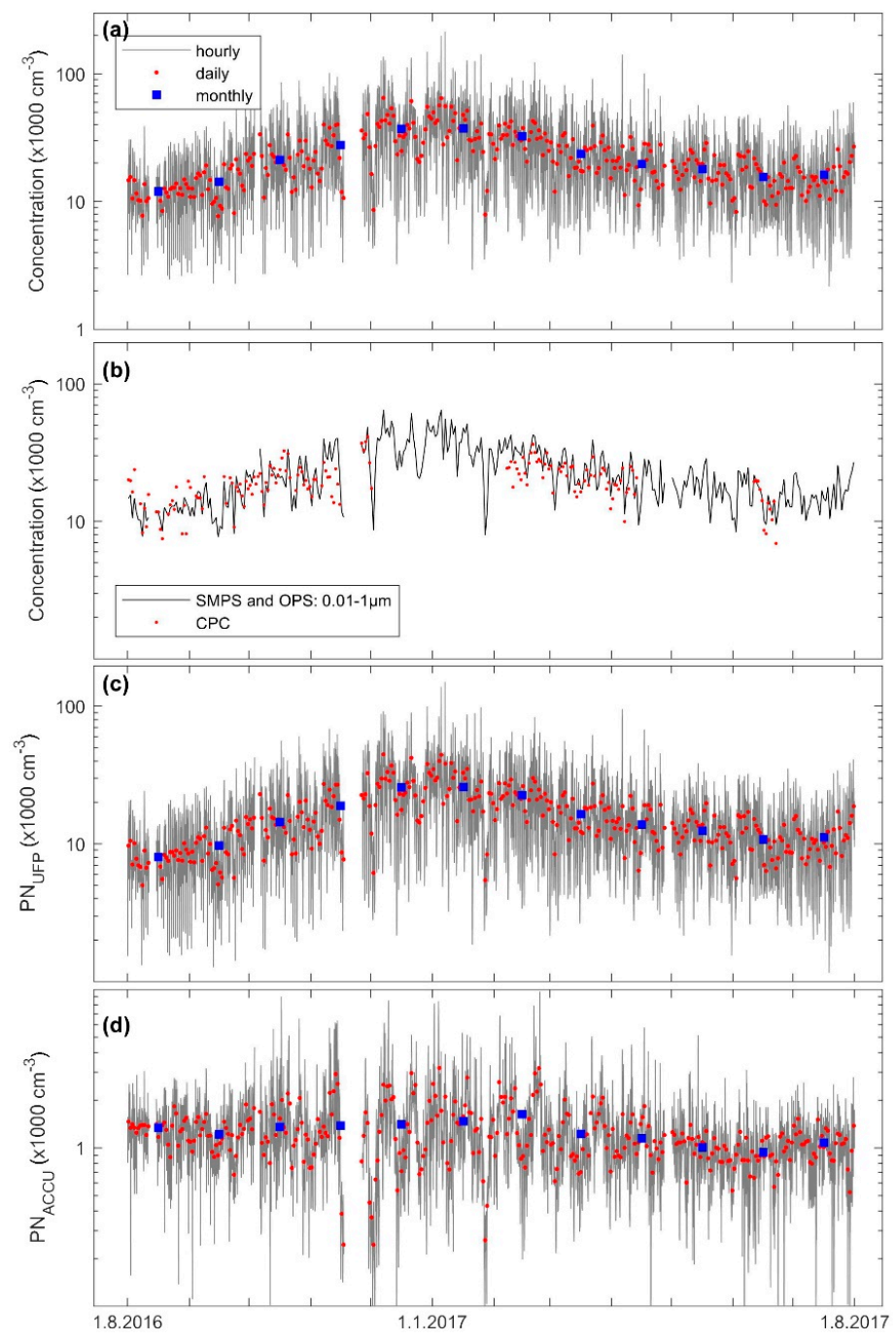

Figure 2. Time series of the (a) submicron particle number concentration, (b) comparison between the condensation particle counter (CPC) and scanning mobility particle sizer (SMPS) + optical particle sizer (OPS) particle number concentrations, and $(\mathbf{c}, \mathbf{d})$ the main particle size fraction concentrations of ultrafine particles $\left(D_{p}<0.1 \mu \mathrm{m}\right)$ and accumulation mode particles $\left(D_{p} 0.1-1 \mu \mathrm{m}\right)$.

Looking closely at the hourly mean $P N_{\text {Sub }}$ concentrations, we can clearly see a diurnal pattern that was more pronounced during the winter than during the summer (Figure 3). Basically, during 
the wintertime, the boundary layer is typically shallower and the aerosol emissions will be more concentrated in the lower atmosphere and their diurnal pattern becomes more pronounced. The main differences between the winter and summer diurnal patterns of the $P N_{S u b}$ concentration were observed in the morning and late night, where the concentrations were high due to increased emissions from traffic during commuting hours. Similar to many other urban environments, the diurnal pattern observed in this study reflects the combustion emissions from traffic activity, which is more during the workdays $[23,24]$. These two peaks are relevant for the morning and afternoon traffic rush hours, which are similar to those noticed in most cities in the other countries [24-27].
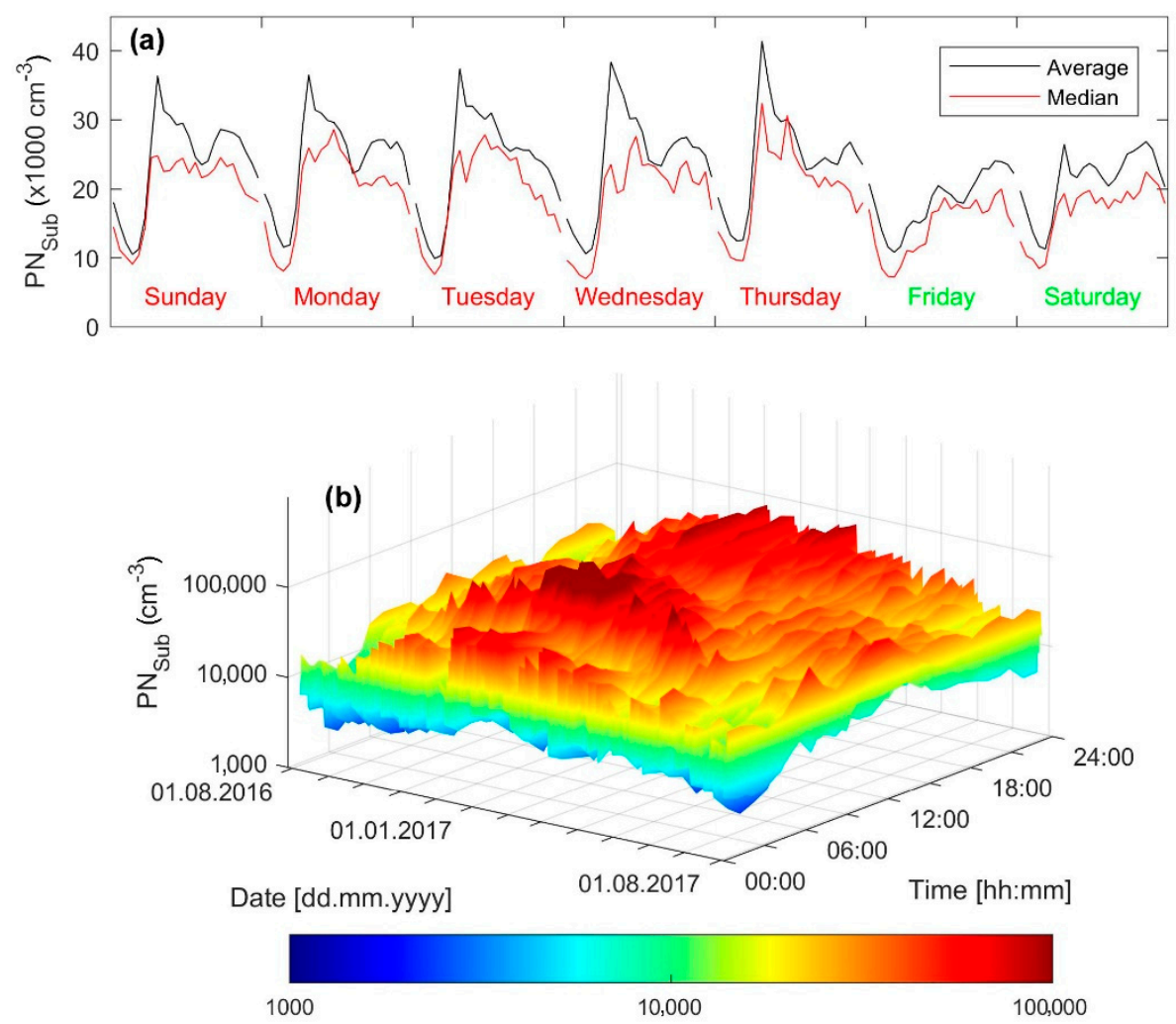

Figure 3. (a) Diurnal pattern of the submicron particle number concentration $(0.01-1 \mu \mathrm{m})$ and (b) date-time spectrum showing the day-to-day and hour-to-hour variation of the number concentration; the color bar scales the number concentration $\left(\mathrm{cm}^{-3}\right)$.

Further analysis on the hourly mean $P N_{S u b}$ concentration revealed a clear weekly cycle in the diurnal patterns with higher concentrations during the workdays (Sunday-Thursday) and lower concentrations during the weekend (Friday-Saturday); see Figure 3a. For example, during the weekends, the peak hourly mean $P N_{S u b}$ concentration was below $2.7 \times 10^{4} \mathrm{~cm}^{-3}$ while during the workdays it was higher than $3.3 \times 10^{4} \mathrm{~cm}^{-3}$. On workdays, $P N_{\text {Sub }}$ diurnal pattern was characterized by a high concentration peak (as high as $4.1 \times 10^{4} \mathrm{~cm}^{-3}$ ) during the morning traffic rush hours and another peak (as high as $2.9 \times 10^{4} \mathrm{~cm}^{-3}$ ) during the afternoon. Regardless of the weekday, the lowest $P N_{S u b}$ was below $1.5 \times 10^{4} \mathrm{~cm}^{-3}$ (on average as low as $1 \times 10^{4} \mathrm{~cm}^{-3}$ ) and it was observed before the morning, when the traffic activity was at minimum in the city.

\subsection{Concentrations of Different Particle Size-Fractions}

The ultrafine particle number concentration $\left(P N_{U F P}\right.$, diameter $\left.<0.1 \mu \mathrm{m}\right)$ fraction was about $93 \%$ of $P N_{S u b}$ concentration. The accumulation mode particle number concentration $\left(P N_{A C C U}\right.$, diameter 0.1-1 $\mu \mathrm{m}$ ) was about $7 \%$ of $P N_{S u b}$. Table S1 lists the monthly statistical values for the main particle size fractions. Typically, the urban/suburban number concentration of fine particles is dominated by 
ultrafine particles [22,24]. This fact has been confirmed in several studies, both experimentally and theoretically [24-35].

In general, the temporal variation of $P N_{U F P}$ concentration (Figures $2 c$, $4 a$ and $5 a$ ) was very close to that of $P N_{S u b}$ concentration; this is true for the seasonal variation, diurnal pattern, and the weekly cycle (Figures $2 \mathrm{a}$ and $3 \mathrm{a}, \mathrm{b})$. As for the $P N_{A C C U}$ concentrations, the weekly cycle also showed distinguished diurnal patterns (Figures $2 \mathrm{~d}$ and $4 \mathrm{~b}$ ). On workdays, the diurnal pattern was characterized by two main peaks, which had rather similar concentrations as high as $1.8 \times 10^{4} \mathrm{~cm}^{-3}$. During the weekends (Friday-Saturday) and Thursday, the $P N_{A C C U}$ concentration was exceptionally high during the late evening, possibly due to increased traffic activities during leisure time in the city.

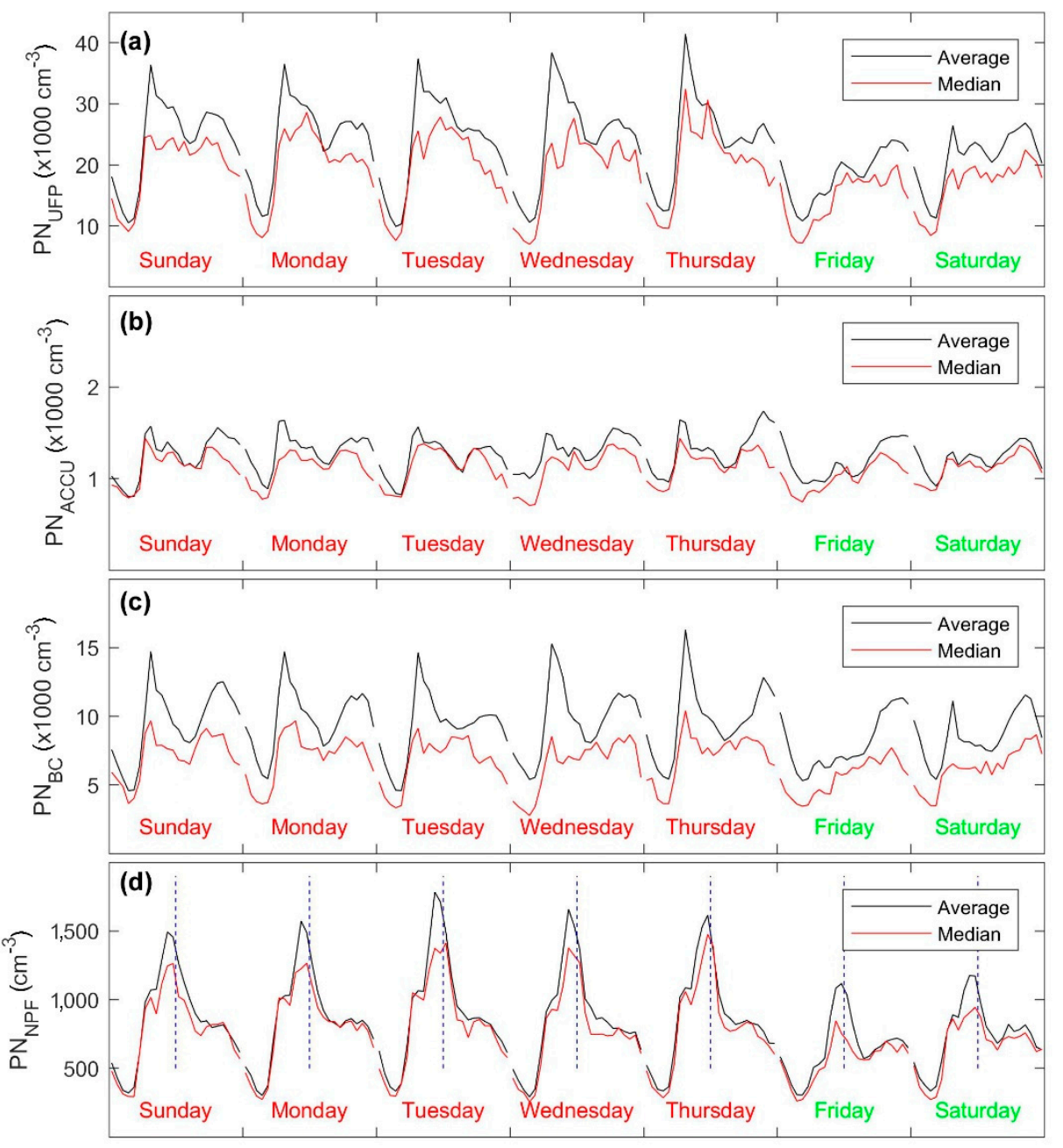

Figure 4. Diurnal pattern of the (a) ultrafine particle number concentration (UFP, diameter $<0.1 \mu \mathrm{m}$ ), (b) accumulation mode particle number concentration (diameter 0.1-1 $\mu \mathrm{m}$ ), (c) an indicator for the temporal variation of black carbon fraction (diameter $0.03-0.25 \mathrm{~nm}$ ), and (d) number concentration in the first channel (diameter 10-15 nm) measured with SMPS; the vertical dashed lines are aligned with the noon time. 
(a)

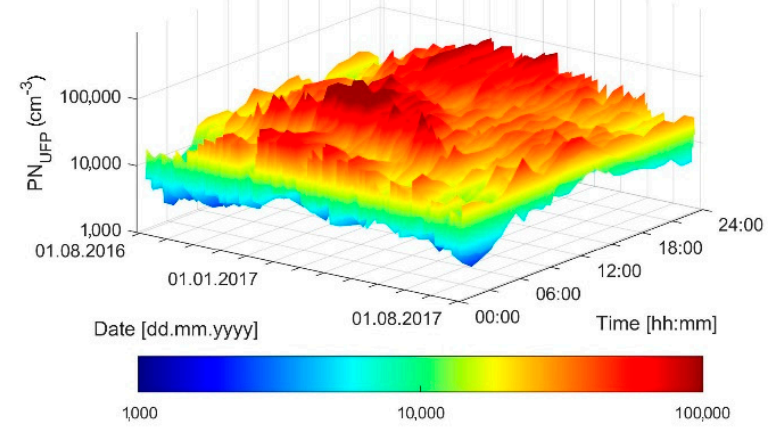

(c)

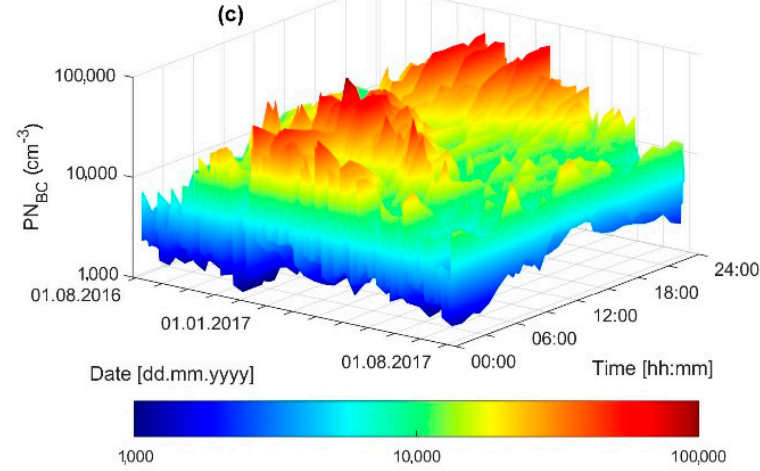

(b)

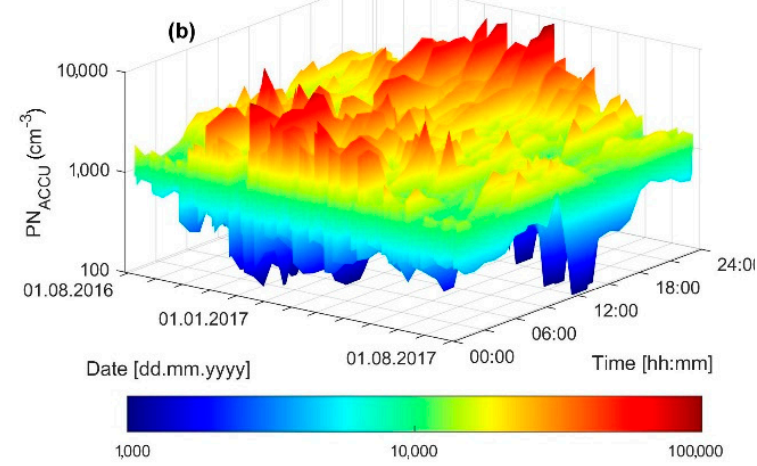

(d)

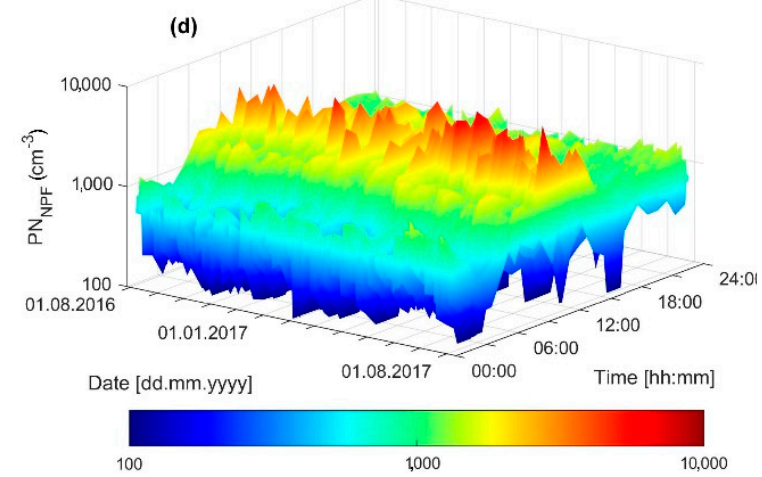

Figure 5. Date-time spectra showing the day-to-day and hour-to-hour variation of (a) ultrafine particle number concentration (UFP, diameter $<0.1 \mu \mathrm{m}$ ), (b) accumulation mode particle number concentration (diameter 0.1-1 $\mu \mathrm{m}$ ), (c) an indicator for the temporal variation of black carbon fraction (diameter 0.03-0.25 nm), (d) number concentration in the first channel (diameter 10-15 nm) measured with SMPS. The color bar scales the number concentration $\left(\mathrm{cm}^{-3}\right)$.

The coarse mode particle number $\left(P N_{\text {Coarse }}\right)$ concentration had a different seasonal pattern than that of $P N_{S u b}$ (Figure 6). According to the monthly average, the $P N_{\text {Coarse }}$ was the highest during the autumn and spring (Table S1). For instance, the monthly $P N_{\text {Coarse }}$ was about 2.5 and $3.8 \mathrm{~cm}^{-3}$, respectively, in October and November. During March and April, the monthly PN $N_{\text {Coarse }}$ was about 3.3 $\mathrm{cm}^{-3}$. As previously reported about this particle size fraction in Amman [19], it had a clear seasonal pattern linked to the sand and dust storms, which are often occurring in the spring season, and local dust resuspension, which are usually dominant in the autumn season. In general, the dust episodes lasted from a few hours to several days. Based on the daily average $P N_{\text {Coarse }}$, it was noticed that dust episodes occurred with concentrations that often exceeded $2 \mathrm{~cm}^{-3}$ and concentrations as high as 14.5 $\mathrm{cm}^{-3}$. Based on the hourly average, the dust episodes increased $P N_{\text {Coarse }}$ to values as high as $46 \mathrm{~cm}^{-3}$. It is already well known that the black carbon has a well-defined size distribution in the submicron fraction. For instance, the distribution of black carbon in the ambient atmosphere, at road side, and from diesel emissions was found to span over the particle diameter range from around $30 \mathrm{~nm}$ up to a couple of hundred nanometers [36,37]. Here, we calculated the number concentrations within the particle diameter range 30-250 nm, which is an indicator of temporal variation of atmospheric black carbon $\left(P N_{B C}\right)$. As expected, this size fraction had temporal variations (Figure $4 \mathrm{c}$ ) very close to those of the total number concentrations but with lower concentrations (Figure 3a). It is important to mention here that what we presented here as $P N_{B C}$ should not be understood as the concentration of black carbon; we only wanted to have an insight into the temporal variation of the black carbon fraction. 

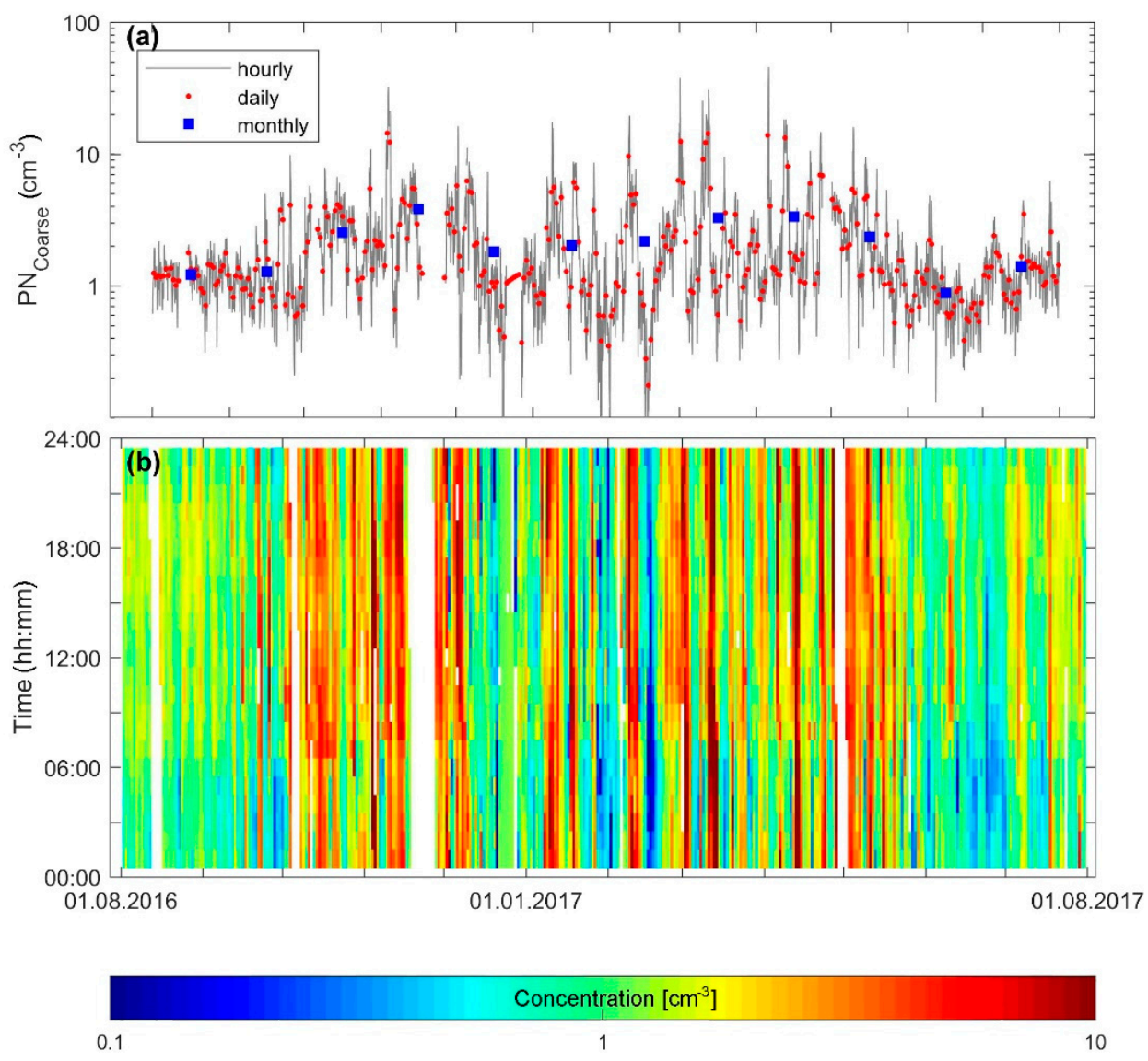

Figure 6. (a) Time series of the coarse mode (diameter 1-10 $\mu \mathrm{m}$ ) particle number concentration and (b) date-time spectrum showing the day-to-day and hour-to-hour variation of the number concentration; the color bar scales the number concentration $\left(\mathrm{cm}^{-3}\right)$.

Except for Amman [17-21,38-40], particle number concentrations and size distributions has never been reported before in urban areas in the Middle East. The previous studies were mainly about some gaseous pollutants; PM mass concentrations, and chemical composition [41-56]. However, the submicron particle number concentrations in Amman are less than what was reported in megacities but still higher (sometimes comparable) than what was reported in Europe, US, and other parts in the world as will be shown in the next paragraph.

Comparison to observations in other urban locations is not straightforward. However, we can summarize the concentrations levels reported worldwide. Many studies reported number concentration in many urban and suburban environments in the EU, America, Asia, and Oceania [34,57-73]. The concentrations varied between cities, locations within the city, and time of observation reflecting the complex behavior of urban aerosols. The observed concentrations in this study (range $6.5 \times 10^{3}-7.7 \times$ $10^{4} \mathrm{~cm}^{-3}$ ) were comparable to other urban locations in the EU, the US, and Oceania where the reported concentrations were in the range $1 \times 10^{3}-6 \times 10^{4} \mathrm{~cm}^{-3}[34,57-59,67-78]$. We should keep in in mind that concentrations on roads are expected to be significantly higher than what can be observed in the ambient conditions [60-66]. Megacities exhibit the highest concentrations of air pollution. Here, we recall the results reported for Indian, Chinese, and Colombian cities [79-83]. Apte et al. [80] reported mean UFP concentrations in New Delhi (India) of $2.8 \times 10^{5} \mathrm{~cm}^{-3}$, which was about eight times higher than that observed in ambient conditions in India. In Beijing and $\mathrm{Xi}^{\prime}$ an (China), the concentrations are comparable to what can be observed in Delhi [81,82]. In Bogota (Colombia), Betancourt et al. [83] showed that the average fine particle number concentrations was about $2 \times 10^{5} \mathrm{~cm}^{-3}$. 
Secondary particle formation, which is often referred to as new particle formation (NPF), is an important process affecting particle number concentrations in both remote and urban environments [6-8,84]. The secondary particles can have a role in haze formation and influence the urban boundary layer and heat island. The NPF process starts from oxidation of precursor vapors and their clustering in sub-3 nm size range [84], which is outside the size range of the instrumentation used in this study. Therefore, it was not possible to make a constructive conclusion about the characteristics of these secondary aerosols in Amman. However, the first particle channel (diameter $10-15 \mathrm{~nm}$ ) in the SMPS can be used as an indicator for the concentrations during NPF events, here denoted as $P N_{N P F}$.

The average diurnal pattern of $P N_{N P F}$ was characterized by high concentrations $\left(0.7 \times 10^{3}-1.1 \times\right.$ $10^{3} \mathrm{~cm}^{-3}$ ) during the daytime and a sharp peak around midday (Figure $4 \mathrm{~d}$ ). The lowest concentration of this particle size fraction was $\sim 320 \mathrm{~cm}^{-3}$ and it was observed between midnight and morning; specifically, between 3 a.m. and 4 a.m.

The most interesting part of the diurnal pattern in this size fraction is the sharp peak around midday. This peak was observed on $\sim 34 \%$ of the measurement days (in total 110 days out of 326 days of valid data) and its alternating occurrence can be seen in Figure $5 \mathrm{~d}$. The peak was often observed around 11 a.m. with a concentration in the range $1.5 \times 10^{3}-1.8 \times 10^{3} \mathrm{~cm}^{-3}$ on workdays and $\sim 1.1 \times$ $10^{3} \mathrm{~cm}^{-3}$ on weekend days. The concentration at the edge of the size distribution started to increase around $8 \mathrm{a} . \mathrm{m}$. and the increase was over around $1 \mathrm{p} . \mathrm{m}$. New particle formation characterization requires deep analysis, which is beyond the scope of this study; therefore, we will not explain this phenomenon any further here.

\subsection{Modal Structure of the Particle Number Size Distribution}

For the purposes of investigating the temporal variation of the particle number concentrations, we focused on two periods representing cold (December-February) and warm (May-August) conditions separately (Figures S4 and S5). During the cold period, the weekly cycle of the diurnal pattern was very distinguished with high mean concentrations on workdays and low mean concentrations on weekends (Figure S4 and Figure 7a-f). On all weekdays, the diurnal pattern was characterized by two peaks: morning and afternoon. The afternoon peak (highest concentration was in the range $3 \times 10^{4}-3.5$ $\times 10^{4} \mathrm{~cm}^{-3}$ ) was rather similar on all weekdays; however, the first peak was higher on workdays than on weekend days. Furthermore, the first peak tended to have higher concentrations from Monday $\left(\sim 4.5 \times 10^{4} \mathrm{~cm}^{-3}\right)$ through Thursday $\left(\sim 6.5 \times 10^{4} \mathrm{~cm}^{-3}\right)$. During this cold period and on all weekdays, the mean particle number size distributions during daytime hours had their peak diameter below 40 $\mathrm{nm}$ whereas during the evening it was over $40 \mathrm{~nm}$ (Figure S6a,b).

During the warm period, the diurnal pattern was rather similar on all weekdays (Figure S5). The daytime mean total concentration $\left(1 \times 10^{4}-2 \times 10^{4} \mathrm{~cm}^{-3}\right)$ during this warm period was lower than that during the cold period (often higher than $3 \times 10^{4} \mathrm{~cm}^{-3}$ ). The differences are possibly explained by the ambient conditions such as enhanced wind speed, higher temperature, and higher boundary layer during the warm period. The secondary particle formation (i.e., NPF events) was very pronounced during the warm period. NPF events were observed almost every day and, consequently, they can be seen to dominate the mean particle number size distribution (Figure $7 \mathrm{~g}-1$ ). The newly formed aerosols were clearly observed with their distinguished nucleation mode with high concentrations before the noon (specifically between 9 a.m. and noon; Figure 7i,j). These newly formed aerosols displayed growth until 6 p.m., when their geometric mean diameter (GMD) reached $\sim 40 \mathrm{~nm}$. 

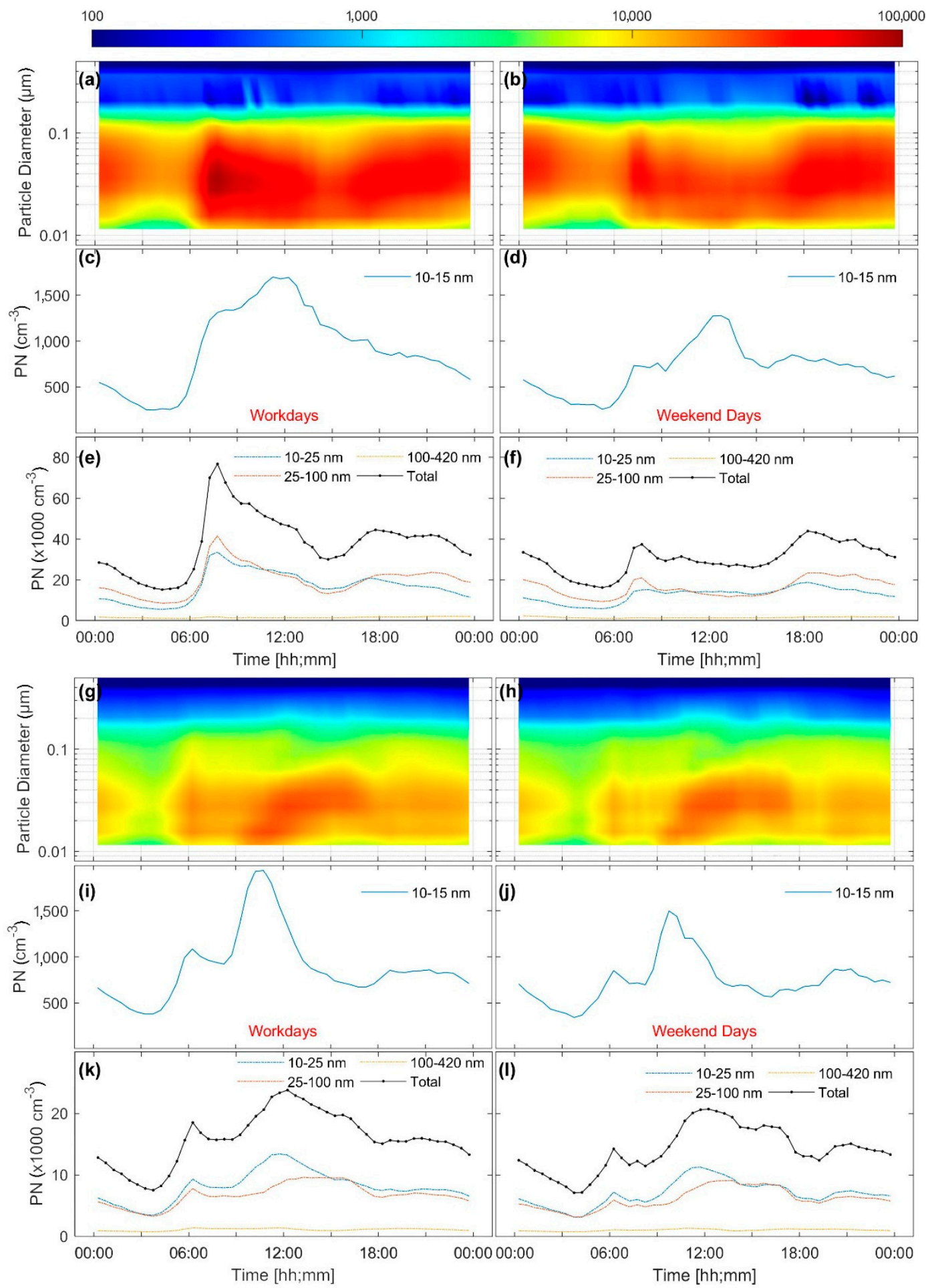

Figure 7. Mean diurnal patterns during (a-f) a cold period (i.e., December-February) and (g-1) warm period (i.e., May-August). Here the color subfigures $(\mathbf{a}, \mathbf{b}, \mathbf{g}, \mathbf{h})$ show the mean particle number size distribution spectra (color bar represents $\mathrm{dN} / \mathrm{d} \log (\mathrm{Dp})\left(\mathrm{cm}^{-3}\right)$ ) and below them are plots for different particle size fractions.

Contrary to the case during the cold period, the mean particle number size distributions at different times of the day during the warm period had three well-separated submicron modes: nucleation, Aitken, and accumulation, in addition to a mode with small GMD that represented the early stage of NPF events (Figure S6c,d). 
Further analysis of the particle number size distributions with respect to the lognormal fitting (i.e., modal structure) revealed that the mode geometric mean diameter $\left(D_{p g, i}\right)$ was about $22 \mathrm{~nm}, 62$ $\mathrm{nm}, 225 \mathrm{~nm}$, and $2.23 \mu \mathrm{m}$ for the nucleation mode, Aitken mode, accumulation mode, and coarse mode, respectively (Figure $8 \mathrm{a}, \mathrm{b}$ ). The corresponding geometric mean values of the mode number concentrations $\left(N_{i}\right)$ were about $9.4 \times 10^{3}, 3.9 \times 10^{3}, 158$, and $1.2 \mathrm{~cm}^{-3}$, respectively (Figure $8 \mathrm{c}-\mathrm{f}$ ). The mode number concentrations of the nucleation, Aitken, and coarse modes were lognormally distributed around their geometric mean values: $22 \mathrm{~nm}, 62 \mathrm{~nm}$, and $2.3 \mu \mathrm{m}$; respectively. However, the accumulation mode number concentration had two distinguished modes with concentrations centered around $50 \mathrm{~cm}^{-3}$ (centered around $D_{p g}=390 \mathrm{~nm}$ ) and $790 \mathrm{~cm}^{-3}$ (centered around $D_{p g}=165$ $\mathrm{nm}$ ); see also Figure $8 \mathrm{a}$. As for the mode geometric variance $\left(\sigma_{p g, i}\right)$, the geometric mean value was about 1.73, 1.67, 1.54, and 1.62, respectively for the nucleation mode, Aitken mode, accumulation mode, and coarse mode (Figure $8 \mathrm{~g}-\mathrm{j}$ ). Interestingly, and as can be seen from Figure $8 \mathrm{a}, D_{p g}$ of the nucleation mode reached values close to $2 \mathrm{~nm}$, which is well below the cut-off diameter of the SMPS $(10 \mathrm{~nm})$. That was basically due to the occurrence of NPF events when a part of the nucleation mode was below the cut-off diameter of the SMPS, which was $10 \mathrm{~nm}$. Furthermore, the smaller the $D_{p g}$, the higher the $N_{i}$ was for the nucleation mode when it occurred below $10 \mathrm{~nm}$.

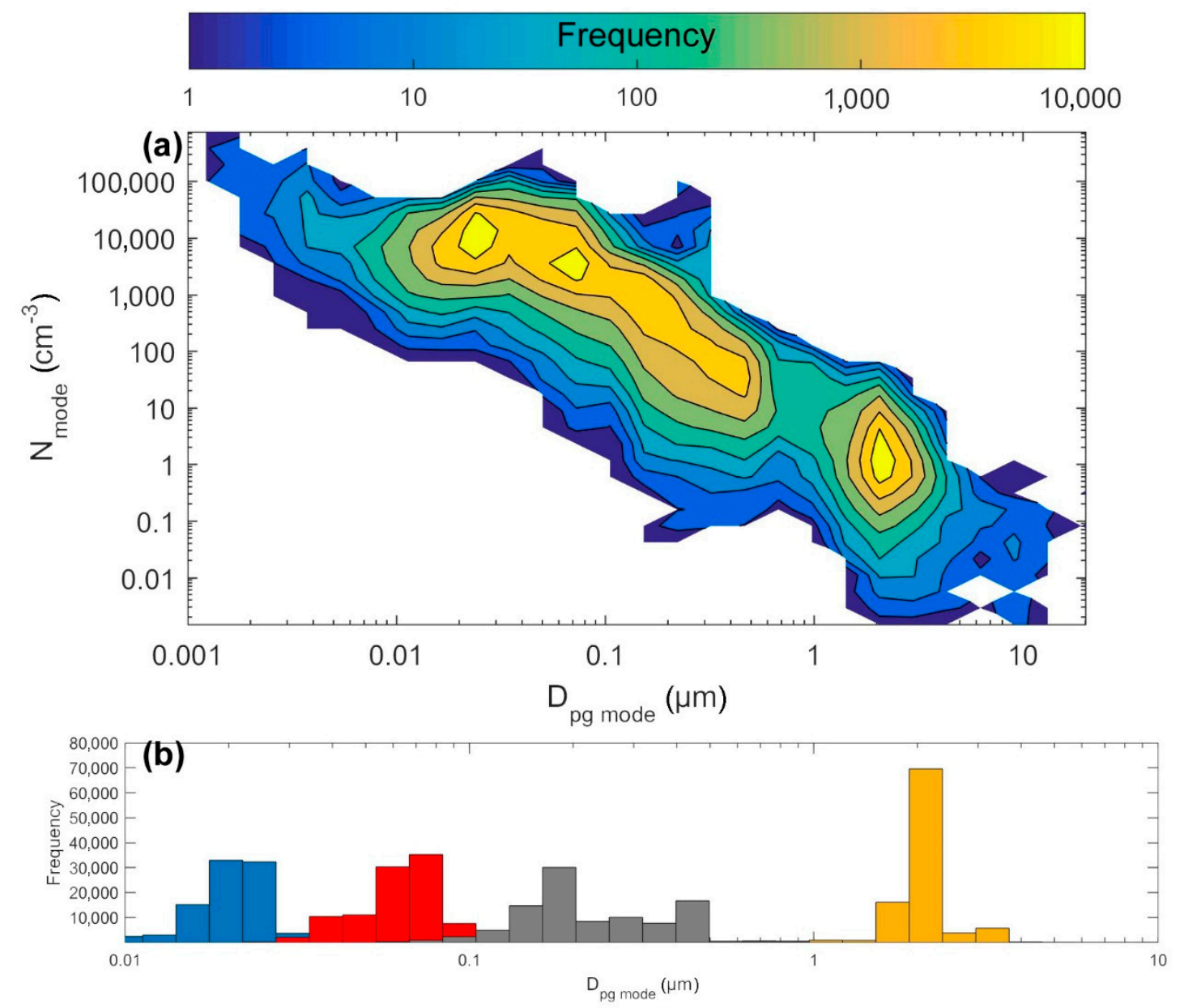

Figure 8. Cont. 

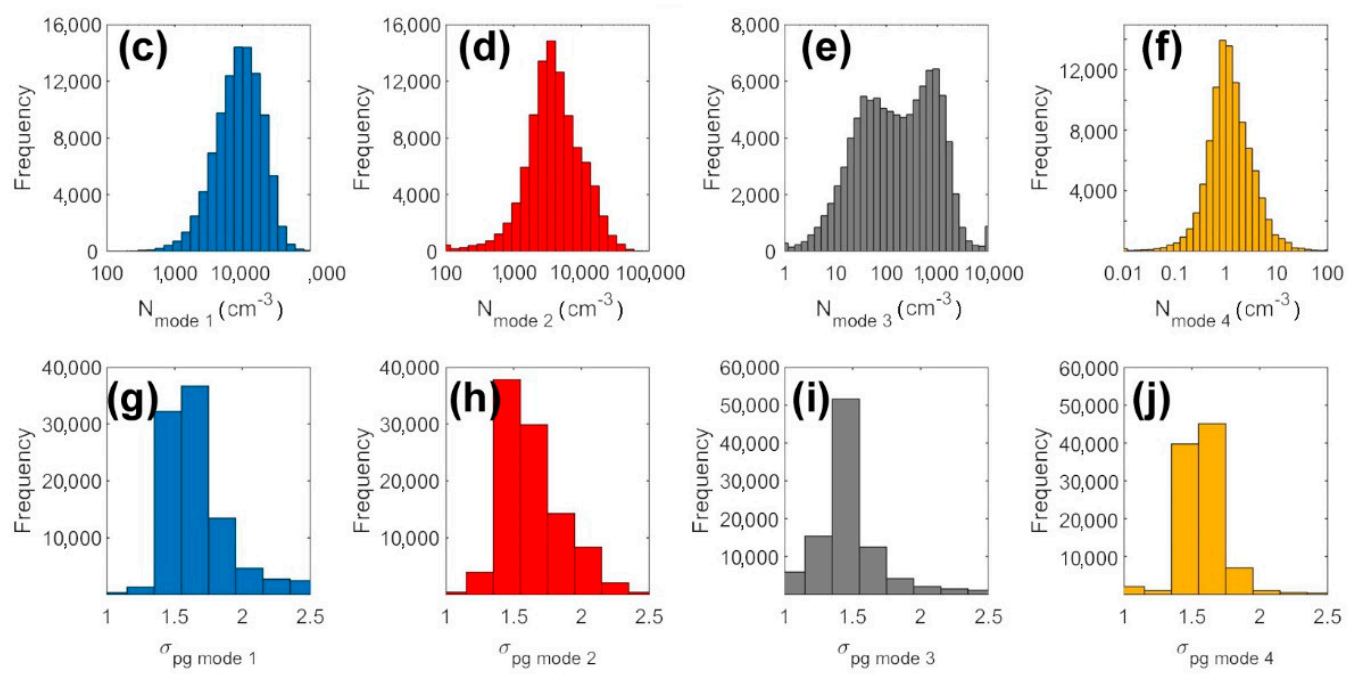

Figure 8. Modal structure of the particle number size distribution derived from the multi-lognormal fitting (5-min average). (a) Modal structure spectrum showing the dominant modes (nucleation, Aitken, accumulation, and coarse modes). Distributions of $(\mathbf{b})$ mode geometric mean diameter $\left(D_{p g}\right),(\mathbf{c}-\mathbf{f})$ mode number concentration $(N)$, and $(\mathbf{g}-\mathbf{j})$ mode geometric variance $\left(\sigma_{p g}\right)$.

\subsection{Effect of Local Weather Conditions}

The meteorological conditions affected the aerosol concentrations in different ways. For example, the submicron particles were affected in a different way than coarse mode particles. Understanding the relationship between urban aerosol concentrations and local meteorological conditions makes it possible to develop predictive models for air pollution [85-88].

In general, the wind speed had a major influence on the particle number concentration (Figure 9). The $P N_{S u b}$ had a decreasing trend with respect to the wind speed (Figure 9a). For instance, the mean $P N_{S u b}$ was about $2.8 \times 10^{4} \mathrm{~cm}^{-3}$ at stagnant conditions and it reached below $1.2 \times 10^{4} \mathrm{~cm}^{-3}$ when the wind speed was above $20 \mathrm{~km} / \mathrm{h}$. This indicates that most of the submicron fraction originated from local sources such as combustion processes (e.g., traffic tailpipe emissions). However, during wind speed $10-15 \mathrm{~km} / \mathrm{h}$, the $P N_{\text {Sub }}$ slightly increased to about $1.2 \times 10^{4} \mathrm{~cm}^{-3}$ and then decreased again with increasing wind speed.

The $P N_{\text {Coarse }}$ concentrations had a U-shaped (centered around $7.5 \mathrm{~km} / \mathrm{h}$ at about $1.5 \mathrm{~cm}^{-3}$ ) with respect the wind speed (Figure $9 \mathrm{~b}$ ). Below $7.5 \mathrm{~km} / \mathrm{h}$, the $P N_{\text {Coarse }}$ concentrations were increasing (reaching about $2.1 \mathrm{~cm}^{-3}$ at stagnant conditions) with decreasing wind speed and above that wind speed the $P N_{\text {Coarse }}$ were increasing (reaching about $5.5 \mathrm{~cm}^{-3}$ at wind speed $20 \mathrm{~km} / \mathrm{h}$ ) with increasing wind speed. The left-hand side of the U-shape curve is related to local sources of dust not induced by the wind; i.e., road dust resuspension due to traffic activities. The right-hand side of the U-shape curve is related to local dust resuspension induced by the wind. Another reason for the increased $P N_{\text {Coarse }}$ concentration at high wind speed is the sand and dust storm (SDS) via long-range transport. The observed influence of wind speed on $P N_{S u b}$ and $P N_{\text {Coarse }}$ concentrations in this study is consistent with previous observations in other urban environments [26,87-95].

The investigation of the effect of temperature on the aerosol concentrations is very complex as illustrated in Figure 9c, d. The mean $P N_{\text {Sub }}$ had the highest concentrations $\left(\sim 3 \times 10^{4} \mathrm{~cm}^{-3}\right)$ during cold conditions $\left(\mathrm{T}<10^{\circ} \mathrm{C}\right)$ and the lowest concentrations $\left(\sim 1.5 \times 10^{4} \mathrm{~cm}^{-3}\right)$ during moderate temperature conditions ( $\mathrm{T}$ in the range $15-25^{\circ} \mathrm{C}$ ). The mean $P N_{\text {Sub }}$ concentrations was proportional to the temperature, when it increased from 25 to $40^{\circ} \mathrm{C}$. The $P N_{\text {Coarse }}$ concentrations were proportional to the temperature in the range $-5-10^{\circ} \mathrm{C}$ and it was rather constant $\left(1-2 \mathrm{~cm}^{-3}\right)$ when the temperature was higher than $10{ }^{\circ} \mathrm{C}$. Our results seem to be in consistent with [96], who found that aerosol concentrations increased with relative humidity during the winter season and decreased with 
temperature. Additionally, Olivares et al. [26] reported that the increase in particle number concentration with decreasing temperature is different for different particle size, and they also showed a distinct correlation between number concentration and (temperature and relative humidity) with higher concentrations during periods with low temperatures or high relative humidity.
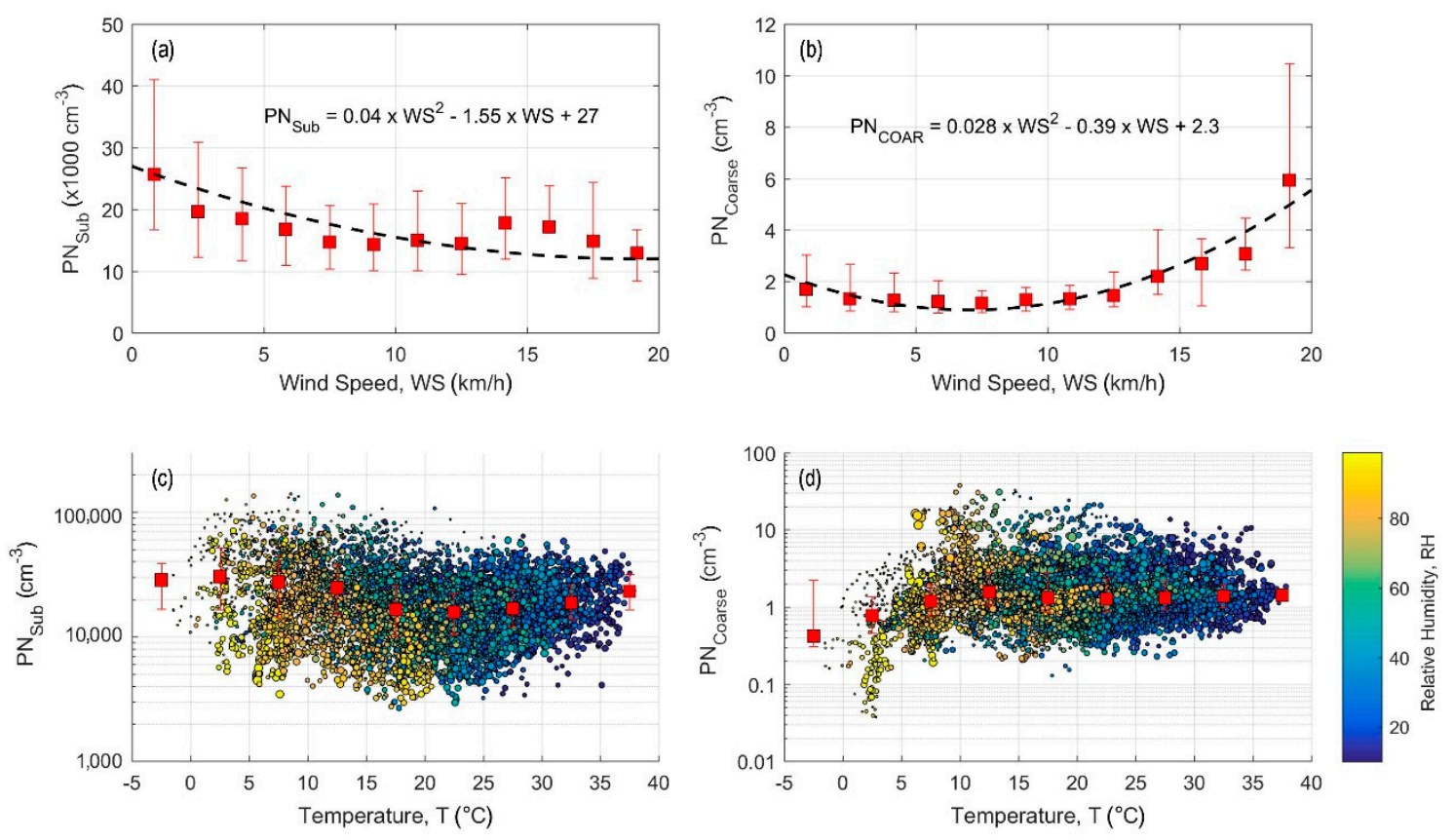

Figure 9. Particle number concentration dependence on the local weather conditions: (a) submicron particles (diameter $<1 \mu \mathrm{m}$ ) with respect to wind speed, (b) coarse mode particles $(1-10 \mu \mathrm{m})$ with respect to wind speed, (c) submicron particles with respect to temperature, and (d) coarse mode particles with respect to temperature. The red squares are the median concentrations with respect to temperature intervals on the $x$-axis and the error bars are the $25 \%$ and $75 \%$. In (c,d), the color codes the relative humidity and the circle size is proportional to the wind speed.

\section{Conclusions}

In this study we aimed at characterizing the aerosol particle number size distribution. We explored the temporal variability (diurnal, weekly, and seasonal) of the number concentrations in Amman, Jordan. Amman can be considered as an example for Middle Eastern urban conditions. Here we utilized a long-term measurement of particle number size distributions over a wide particle diameter range $(0.01-10 \mu \mathrm{m})$, which was combined from a Nano-Scanning Mobility Particle Sizer (Nano SMPS) and an Optical Particle Sizer (OPS). We also investigated the modal structure of the aerosol population by using the multi-lognormal distribution function (DO-FIT).

The submicron particle number concentrations $\left(P N_{S u b}\right)$ and the coarse mode particle number concentration $\left(P N_{\text {Coarse }}\right)$ had distinguished seasonal variations. Based on the monthly average, $P N_{S u b}$ was higher in the winter $\left(3.3 \times 10^{4}-3.7 \times 10^{4} \mathrm{~cm}^{-3}\right.$, December-February) than in the summer and early autumn $\left(1.2 \times 10^{4}-1.6 \times 10^{4} \mathrm{~cm}^{-3}\right.$, June-September). The 24 -h mean $P N_{S u b}$ was in the range $6.5 \times$ $10^{3}-7.7 \times 10^{4} \mathrm{~cm}^{-3}$ and the hourly means was in the range $2.2 \times 10^{3}-2.1 \times 10^{5} \mathrm{~cm}^{-3}$. According to the monthly average, the $P N_{\text {Coarse }}$ was the highest during the autumn $\left(3.8 \mathrm{~cm}^{-3}\right.$, November) and spring $\left(3.3 \mathrm{~cm}^{-3}\right.$, April). The $P N_{\text {Coarse }}$ seasonal pattern is most likely linked to the sand and dust storms (often occurring in spring) and local dust resuspension (dominant autumn). It was clear within this study that there is a clear influence of new particle formation (NPF) on the submicron aerosols and Sand and Dust Storm (SDS) on coarse mode aerosols. However, these phenomena require further detailed analysis that will be made in upcoming studies. 
The $P N_{\text {Sub }}$ concentrations was characterized by a diurnal pattern, which was more pronounced during the winter than during the summer. The diurnal pattern was also different between workdays and weekends reflecting a clear weekly cycle: higher concentrations during the workdays (Sunday-Thursday; over $3.3 \times 10^{4} \mathrm{~cm}^{-3}$ ) and lower concentrations during the weekend (Friday-Saturday; below $2.7 \times 10^{4} \mathrm{~cm}^{-3}$ ). On workdays, $P N_{S u b}$ diurnal pattern was characterized with a high concentration peak (as high as $4.1 \times 10^{4} \mathrm{~cm}^{-3}$ ) during the morning traffic rush hours and another peak (as high as $2.9 \times 10^{4} \mathrm{~cm}^{-3}$ ) during the afternoon. In general, the seasonal, weekly, and diurnal variation of $P N_{S u b}$ is clearly depicting the traffic activities suggesting that traffic emissions are a major contributor to submicron aerosols. The ultrafine particle number concentration $\left(P N_{U F P}\right.$, diameter $<0.1$ $\mu \mathrm{m})$ fraction was about $93 \%$ of $P N_{S u b}$ concentration whereas that of the accumulation mode particle number concentration $\left(P N_{A C C}\right.$, diameter $\left.0.1-1 \mu \mathrm{m}\right)$ was about $7 \%$ of $P N_{S u b}$. The temporal variation of $P N_{U F P}$ and $P N_{A C C U}$ concentration was very close to that of $P N_{S u b}$ concentration.

We investigated the modal structure of the measured aerosols $(0.01-10 \mathrm{~mm})$. During cold conditions (December-February), the mean particle number size distributions during daytime hours had peak diameters smaller than $40 \mathrm{~nm}$ whereas during the evening it was larger than $40 \mathrm{~nm}$. During warm conditions (May-August), the mean particle number size distributions at different times of the day had three well-separated submicron modes: nucleation, Aitken, and accumulation in addition to a mode with small GMD that represented the early stage of NPF events. The mode geometric mean diameter $\left(D_{p g, i}\right)$ was about $22 \mathrm{~nm}, 62 \mathrm{~nm}, 225 \mathrm{~nm}$, and $2.23 \mu \mathrm{m}$ for the nucleation mode, Aitken mode, accumulation mode, and coarse mode, respectively. The corresponding mode number concentrations $\left(N_{i}\right)$ were about $9.4 \times 10^{3}, 3.9 \times 10^{3}, 158$, and $1.2 \mathrm{~cm}^{-3}$, respectively. In fact, the accumulation mode number concentration had two distinguished groups with concentrations centered around $50 \mathrm{~cm}^{-3}$ (centered around $D_{p g}=165 \mathrm{~nm}$ ) and $790 \mathrm{~cm}^{-3}$ (centered around $D_{p g}=390 \mathrm{~nm}$ ). Interestingly, $D_{p g}$ of the nucleation mode reached values close to $2 \mathrm{~nm}$, which is well below the cut-off diameter of the SMPS $(10 \mathrm{~nm})$ but still can be depicted by the DO-FIT algorithm of the multi-lognormal fitting. That was basically due to the occurrence of NPF events.

The local meteorological conditions affected the aerosol concentrations in different ways. The wind speed and temperature had a major impact on the aerosol concentrations. During stagnant conditions, the mean $P N_{\text {Sub }}$ concentration was $\sim 2.8 \times 10^{4} \mathrm{~cm}^{-3}$ and $P N_{\text {Coarse }}$ concentration was $\sim 2.1$ $\mathrm{cm}^{-3}$. In general, the $P N_{\text {Coarse }}$ concentration had a U-shape with respect to wind speed whereas the $P N_{\text {Sub }}$ concentrations decreased with wind speed. The mean $P N_{S u b}$ had the highest concentrations ( 3 $\left.\times 10^{4} \mathrm{~cm}^{-3}\right)$ during cold conditions and the lowest concentrations $\left(\sim 1.5 \times 10^{4} \mathrm{~cm}^{-3}\right)$ during moderate temperature conditions. The $P N_{\text {Coarse }}$ concentrations were proportional to the temperature in the range $-5-10{ }^{\circ} \mathrm{C}$ and they were rather constant $\left(1-2 \mathrm{~cm}^{-3}\right)$ when the temperature was higher than $10^{\circ} \mathrm{C}$.

Supplementary Materials: The following are available online at http://www.mdpi.com/2073-4433/10/11/710/s1, Figure S1: (a) A Map of Jordan showing the geographical location of Amman. (b) A Map of Amman showing the campus of the University of Jordan (shaded area) and (c) a detailed map of the campus of the University of Jordan, showing the sampling location (shaded area) in the middle of the campus., Figure S2: Experimental penetration efficiency through the sampling lines (tubing and diffusion drier), Figure S3: Regression between the number concentrations measured with the CPC versus (a) number concentration measured with the SMPS (Dp 0.01-0.42 $\mu \mathrm{m})$ and (b) number concentration derived from the combined particle number size distribution measurements (SMPS and OPS, $D p$ 0.01-1 $\mu \mathrm{m}$ ), Figure S4: Weekly cycle and the diurnal pattern during a cold period (i.e., winter: December-February): (a) mean particle number size distribution spectra and (b-c) concentrations of different particle size fractions. The color bar represents dN/dlog $(D p)\left(\mathrm{cm}^{-3}\right)$, Figure S5: Weekly cycle and the diurnal pattern during a cold period (i.e., summer: May-August): (a) mean particle number size distribution spectra and $(\mathrm{b}-\mathrm{c})$ concentrations of different particle size fractions. The color bar represents $\mathrm{dN} / \mathrm{dlog}(D p)\left(\mathrm{cm}^{-3}\right)$, Figure S6: Mean particle number size distributions during $(a, b)$ cold period (i.e., winter: December-February) and (c,d) warm period (i.e., summer: May-August). The mean distributions are shown for different times of the day on workdays $(a, c)$ and weekend days $(b, d)$, Table S1: Monthly statistics for the main particle size fractions (concentrations in units of $\mathrm{cm}^{-3}$ ). 
Author Contributions: Conceptualization, T.H.; methodology, T.H.; validation, T.H.; formal analysis, T.H., S.H. and L.D.; investigation, T.H.; resources, T.H.; data curation, T.H.; writing-original draft preparation, T.H.; writing-review and editing, T.H., L.D., S.H., T.P. and M.K.; visualization, T.H. and L.D.; supervision, T.H.; project administration, T.H.; funding acquisition, T.H., T.P. and M.K.

Funding: This research was funded by the Scientific Research Support Fund (SRF, project number BAS-1-2-2015) at the Jordanian Ministry of Higher Education and the Deanship of Academic Research (DAR, project number 1516) at the University of Jordan. This research was part of a close collaboration between the University of Jordan and the Institute for Atmospheric and Earth System Research (INAR / Physics, University of Helsinki) via ERC advanced grant No. 742206, the European Union's Horizon 2020 research and innovation program under grant agreement No. 654109, the Academy of Finland Center of Excellence (project No. 272041), ERA-PLANET (www.era-planet.eu), trans-national project SMURBS (www.smurbs.eu, grant agreement n. 689443 funded under the EU Horizon 2020 Framework Programme and Academy of Finland via the Center of Excellence in Atmospheric sciences and NanoBioMass (project number 1307537).

Acknowledgments: This manuscript was written and completed during the sabbatical leave of the first author (Tareq Hussein) that was spent at the University of Helsinki and supported by the University of Jordan during 2019. Open access funding provided by University of Helsinki.

Conflicts of Interest: The authors declare no conflict of interest.

\section{References}

1. Lelieveld, J.; Evans, J.S.; Fnais, M.; Giannadaki, D.; Pozzer, A. The contribution of outdoor air pollution sources to premature mortality on a global scale. Nature 2015, 525, 367-371. [CrossRef] [PubMed]

2. IPCC. Climate Change 2013: The Physical Science Basis. Contribution of Working Group I to the Fifth Assessment Report of the Intergovernmental Panel on Climate Change; Cambridge University Press: Cambridge, MA, USA, 2013.

3. Oberdörster, G.; Sharp, Z.; Atudorei, V.; Elder, A.; Gelein, R.; Kreyling, W.; Cox, C. Translocation of inhaled ultrafine particles to the brain. Inhal. Toxicol. 2004, 16, 437-445. [CrossRef] [PubMed]

4. Kerminen, V.M.; Paramonov, M.; Anttila, T.; Riipinen, I.; Fountoukis, C.; Korhonen, H.; Asmi, E.; Laakso, L.; Lihavainen, H.; Swietlicki, E.; et al. Cloud condensation nuclei production associated with atmospheric nucleation: A synthesis based on existing literature and new results. Atmos. Chem. Phys. 2012, 12, 12037-12059. [CrossRef]

5. Merikanto, J.; Spracklen, D.; Mann, G.; Pickering, S.; Carslaw, K. Impact of nucleation on global CCN. Atmos. Chem. Phys. 2009, 9, 8601-8616. [CrossRef]

6. Kulmala, M.; Vehkamäki, H.; Petäjä, T.; Dal Maso, M.; Lauri, A.; Kerminen, V.-M.; Birmili, W.; McMurry, P.H. Formation and growth rates of ultrafine atmospheric particles: A review of observations. J. Aerosol Sci. 2004, 35, 143-176. [CrossRef]

7. Kerminen, V.-M.; Chen, X.; Vakkari, V.; Petäjä, T.; Kulmala, M.; Bianchi, F. Atmospheric new particle formation and growth: Review of field observations. Environ. Res. Lett. 2018, 13, 103003. [CrossRef]

8. Chu, B.; Kerminen, V.M.; Bianchi, F.; Yan, C.; Petäjä, T.; Kulmala, M. Atmospheric new particle formation in China. Atmos. Chem. Phys. 2019, 19, 115-138. [CrossRef]

9. Rönkkö, T.; Kuuluvainen, H.; Karjalainen, P.; Keskinen, J.; Hillamo, R.; Niemi, J.V.; Pirjola, L.; Timonen, H.J.; Saarikoski, S.; Saukko, E.; et al. Traffic is a major source of atmospheric nanocluster aerosol. Proc. Natl. Acad. Sci. USA 2017, 114, 7549-7554. [CrossRef]

10. Dall'Osto, M.; Harrison, R.M. Urban organic aerosols measured by single particle mass spectrometry in the megacity of London. Atmos. Chem. Phys. 2012, 12, 4127-4142. [CrossRef]

11. Pikridas, M.; Riipinen, I.; Hildebrandt, L.; Kostenidou, E.; Manninen, H.; Mihalopoulos, N.; Kalivitis, N.; Burkhart, J.F.; Stohl, A.; Kulmala, M.; et al. New particle formation at a remote site in the eastern Mediterranean. J. Geophys. Res. Atmos. 2012, 117. [CrossRef]

12. Ždímal, V.; Smolík, J.; Eleftheriadis, K.; Wagner, Z.; Housiadas, C.; Mihalopoulos, N.; Mikuška, P.; Večeřa, Z.; Kopanakis, I.; Lazaridis, M. Dynamics of atmospheric aerosol number size distributions in the eastern Mediterranean during the "SUB-AERO" Project. Water Air Soil Pollut. 2011, 214, 133-146. [CrossRef]

13. Reche, C.; Viana, M.; Pandolfi, M.; Alastuey, A.; Moreno, T.; Amato, F.; Ripoll, A.; Querol, X. Urban NH3 levels and sources in a Mediterranean environment. Atmos. Environ. 2012, 57, 153-164. [CrossRef] 
14. Kopanakis, I.; Chatoutsidou, S.; Torseth, K.; Glytsos, T.; Lazaridis, M. Particle number size distribution in the eastern Mediterranean: Formation and growth rates of ultrafine airborne atmospheric particles. Atmos. Environ. 2013, 77, 790-802. [CrossRef]

15. Lihavainen, H.; Alghamdi, M.A.; Hyvärinen, A.-P.; Hussein, T.; Aaltonen, V.; Abdelmaksoud, A.S.; Al-Jeelani, H.; Almazroui, M.; Almehmadi, F.M.; Al Zawad, F.M.; et al. Aerosols Physical properties at Hada Al Sham, Western Saudi Arabia. Atmos. Environ. 2016, 135, 109-117. [CrossRef]

16. Hakala, S.; Alghamdi, M.A.; Paasonen, P.; Vakkari, V.; Khoder, M.; Neitola, K.; Dada, L.; Abdelmaksoud, A.S.; Al-Jeelani, H.; Shabbaj, I.I.; et al. New particle formation, growth and apparent shrinkage at a rural background site in western Saudi Arabia. Atmos. Chem. Phys. 2019, 19, 10537-10555. [CrossRef]

17. Hussein, T.; Boor, B.E.; dos Santos, V.N.; Kangasluoma, J.; Petäjä, T.; Lihavainen, H. Mobile Aerosol Measurement in the Eastern Mediterranean-A Utilization of Portable Instruments. Aerosol Air Qual. Res. 2017, 17, 1875-1886. [CrossRef]

18. Hussein, T.; Sogacheva, L.; Petäjä, T. Accumulation and Coarse Modes Particle Concentrations during Dew Formation and Precipitation. Aerosol Air Qual. Res. 2018, 18, 2929-2938. [CrossRef]

19. Hussein, T.; Juwhari, H.; Al Kuisi, M.; Alkattan, H.; Lahlouh, B.; Al-Hunaiti, A. Accumulation and Coarse Modes Aerosols Concentrations and Carbonaceous Contents in the Urban Background Atmosphere in Amman-Jordan. Arab. J. Geosci. 2018, 11, 617. [CrossRef]

20. Hussein, T.; Saleh, S.S.A.; dos Santos, V.N.; Abdullah, H.; Boor, B.E. Black Carbon and Particulate Matter Concentrations in Eastern Mediterranean Urban Conditions-An Assessment Based on Integrated Stationary and Mobile Observations. Atmosphere 2019, 10, 323. [CrossRef]

21. Hussein, T.; Betar, A. Size-Fractionated Number and Mass Concentrations in the Urban Background Atmosphere during Spring 2014 in Amman-Jordan. Jordan J. Phys. 2017, 10, 51-60.

22. Hussein, T.; Dal Maso, M.; Petäjä, T.; Koponen, I.K.; Paatero, P.; Aalto, P.P.; Hämeri, K.; Kulmala, M. Evaluation of an automatic algorithm for fitting the particle number size distributions. Boreal Environ. Res. 2005, 10, 337-355.

23. Hussein, T.; Hämeri, K.; Kulmala, M. Long-term indoor-outdoor aerosol measurement in Helsinki, Finland. Boreal Environ Res. 2002, 7, 141-150.

24. Hussein, T.; Puustinen, A.; Aalto, P.P.; Mäkelä, J.M.; Hämeri, K.; Kulmala, M. Urban aerosol number size distributions. Atoms. Chem. Phys. 2004, 4, 391-411. [CrossRef]

25. Wehner, B.; Wiedensohler, A. Long term measurements of submicrometer urban aerosols: Statistical analysis for correlations with meteorological conditions and trace Gases. Atoms. Chem. Phys. 2003, 3, 867-879. [CrossRef]

26. Olivares, G.; Johansson, C.; Ström, J.; Hansson, H.C. The role of ambient temperature of particle number concentrations in a street canyon. Atmos. Environ. 2007, 41, 2145-2166. [CrossRef]

27. Wehner, B.; Wiedensohler, A.; Tuch, T.M.; Wu, Z.J.; Hu, M.; Slanina, J.; Kiang, C.S. Variability of the Aerosol Number Size Distribution in Beijing, China: New Particle Formation, Dust Storms, and High continental Background. Geophys. Res. 2004, 31. [CrossRef]

28. Wehner, B.; Wiedensohler, A.; Heintzenberg, J. Submicrometer aerosol size distributions and mass concentration of the Millenium fireworks 2000 in Leipzig, Germany. J. Aerosol Sci. 2000, 31, 1489-1493. [CrossRef]

29. Jung, C.H.; Kim, Y.P.; Lee, K.W. Simulation of the influence of coarse mode particles on the properties of fine mode particles. Aerosol Sci. Technol. 2002, 33, 1201-1216. [CrossRef]

30. Mönkkönen, P.; Koponen, I.K.; Lehtinen, K.E.J.; Uma, R.; Srinivasan, D.; Hämeri, K.; Kulmala, M. Technical note: Death of nucleation and Aitken mode particles: Observations at extreme atmospheric conditions and their theoretical explanation. J. Aerosol Sci. 2004, 35, 781-787. [CrossRef]

31. Cheng, T.; Lu, D.; Chen, H.; Xu, Y. Physical characteristics of dust aerosol over Hunshan Dake sandland in Northern China. Atmos. Environ. 2005, 39, 1237-1243. [CrossRef]

32. Mej1a, J.F.; Morawska, L.; Mengersen, K. Spatial variation in particle number size distributions in a large metropolitan area. Atmos. Chem. Phys. 2008, 8, 1127-1138. [CrossRef]

33. Wu, Z.; Hu, M.; Lin, P.; Liu, S.; Wehner, B.; Widensohler, A. Particle number size distribution in the urban atmosphere of Beijing, China. Atmos. Environ. 2008, 42, 7967-7980. [CrossRef] 
34. Birmili, W.; Alaviippola, B.; Hinneburg, D.; Knoth, O.; Touch, T.; Borken-Kleefeld, J.; Schacht, A. Dispersion of traffic-related exhaust particles near the Berlin urban motorway-Estimation of fleet emission factors. Atmos. Chem. Phys. 2009, 9, 2355-2374. [CrossRef]

35. Oliveira, C.; Alves, C.; Pio, C.A. Aerosol particle size distributions at a traffic exposed site and an urban background location in Oporto, Portugal. Quim. Nova 2009, 32, 928-933. [CrossRef]

36. Ning, Z.; Chan, K.L.; Wong, K.C.; Westerdahl, D.; Močnik, G.; Zhou, J.H.; Cheung, C.S. Black carbon mass size distributions of diesel exhaust and urban aerosols measured using differential mobility analyzer in tandem with Aethalometer. Atmos. Environ. 2013, 80, 31-40. [CrossRef]

37. Wu, Y.; Wang, X.; Tao, J.; Huang, R.; Tian, P.; Cao, J.; Zhang, L.; Ho, K.-F.; Han, Z.; Zhang, R. Size distribution and source of black carbon aerosol in urban Beijing during winter haze episodes. Atmos. Chem. Phys. 2017, 17, 7965-7975. [CrossRef]

38. Hussein, T.; Abu Al-Ruz, R.; Petäjä, T.; Junninen, H.; Arafah, D.-E.; Hämeri, K.; Kulmala, M. Local air pollution versus short-range transported dust episodes: A comparative study for submicron particle number concentration. Aerosol Air Qual. Res. 2011, 11, 109-119. [CrossRef]

39. Hussein, T.; Halayka, M.; Abu Al-Ruz, R.; Abdullah, H.; Mølgaard, B.; Petäjä, T. Fine Particle Number Concentrations in Amman and Zarqa during Spring 2014. Jordan J. Phys. 2016, 9, 31-46.

40. Saleh, S.S.A.; Shilbayeh, Z.; Alkattan, H.; Al-Refie, M.R.; Jaghbeir, O.; Hussein, T. Temporal Variations of Submicron Particle Number Concentrations at an Urban Background Site in Amman-Jordan. Jordan J. Earth Environ. Sci. 2019, 10, 37-44.

41. Abi-Esber, L.; El-Fadel, M. Indoor to outdoor air quality associations with self pollution implications inside passenger car cabins. Atoms. Environ. 2013, 81, 450-463. [CrossRef]

42. Alam, K.; Trautmann, T.; Blaschke, T.; Subhan, F. Changes in aerosol optical properties due to dust storms in the Middle East and Southwest Asia. Remote Sens. Environ. 2014, 143, 216-227. [CrossRef]

43. Roumie, M.; Chiari, M.; Srour, A.; Sa'adeh, H.; Reslan, A.; Sultan, M.; Ahmad, M.; Calzolai, G.; Nava, S.; Zubaidi, T.; et al. Evaluation and mapping of $\mathrm{PM}_{2.5}$ atmospheric aerosols in Arasia region using PIXE and gravimetric measurements. Nucl. Inst. Meth. Phys. Res. B 2016, 371, 381-386. [CrossRef]

44. Hussein, T.; Alghamdi, M.A.; Khoder, M.; AbdelMaksoud, A.S.; Al-Jeelani, H.; Goknil, M.K.; Shabbaj, I.I.; Almehmadi, F.M.; Hyvärinen, A.; Lihavainen, H.; et al. Particulate matter and number concentrations of particles larger than $0.25 \mu \mathrm{m}$ in the urban atmosphere of Jeddah, Saudi Arabia. Aerosol Air Qual. Res. 2014, 14, 1383-1391. [CrossRef]

45. Alghamdi, M.A.; Khoder, M.; Abdelmaksoud, A.S.; Harrison, R.M.; Hussein, T.; Lihavainen, H.; Al-Jeelani, H.; Goknil, M.H.; Shabbaj, I.I.; Almehmadi, F.M.; et al. Seasonal and diurnal variations of BTEX and their potential for ozone formation in the urban background atmosphere of the coastal city Jeddah, Saudi Arabia. Air Qual. Atmos. Health 2014, 7, 467-480. [CrossRef]

46. Alghamdi, M.A.; Khoder, M.; Harrison, R.M.; Hyvärinen, A.-P.; Hussein, T.; Al-Jeelani, H.; Abdelmaksoud, A.S.; Goknil, M.H.; Shabbaj, I.I.; Almehmadi, F.M.; et al. Temporal Variations of $\mathrm{O}_{3}$ and $\mathrm{NO}_{\mathrm{x}}$ in the Urban Background Atmosphere of the Coastal City Jeddah, Saudi Arabia. Atmos. Environ. 2014, 94, 205-214. [CrossRef]

47. Boman, J.; Shaltout, A.A.; Abozied, A.M.; Hassan, S.K. On the elemental composition of PM 2.5 in central Cairo, Egypt. X-ray Spectrom. 2013, 42, 276-283. [CrossRef]

48. Basha, G.; Phanikumar, D.V.; Kumar, K.N.; Ouarda, T.B.M.J.; Marpu, P.R. Investigation of aerosol optical, physical, and radiative characteristics of a severe dust storm observed over UAE. Remote Sen. Environ. 2015, 169, 404. [CrossRef]

49. Engelbrecht, J.P.; Jayanty, R.K.M. Assessing sources of airborne mineral dust and other aerosols, in Iraq. Aeol. Res. 2013, 9, 153-160. [CrossRef]

50. Engelbrecht, J.P.; McDonald, E.V.; Gillies, J.A.; Jayanty, R.K.M.; Casuccio, G.; Gertler, A.W. Characterizing Mineral Dusts and Other Aerosols from the Middle East-Part 1: Ambient Sampling. Inhal. Toxicol. 2009, 21, 297-326. [CrossRef]

51. Engelbrecht, J.P.; McDonald, E.V.; Gillies, J.A.; Jayanty, R.K.M.; Casuccio, G.; Gertler, A.W. Characterizing Mineral Dusts and Other Aerosols from the Middle East-Part 2: Grab Samples and Re-Suspensions. Inhal. Toxicol. 2009, 21, 327-336. [CrossRef]

52. Habeebullah, T.M. An Analysis of Air Pollution in Makkah-A View Point of Source Identification. Environ. Asia 2013, 2, 11-17. 
53. Moustafa, M.; Mohamed, A.; Ahmed, A.-R.; Nazmy, H. Mass size distributions of elemental aerosols in industrial area. J. Adv. Res. 2015, 6, 827-832. [CrossRef] [PubMed]

54. Notaro, M.; Yu, Y.; Kalashnikova, O.V. Regime shift in Arabian dust activity, triggered by persistent Fertile Crescent drought. J. Geophys. Res. Atmos. 2015, 120, 10229-10249. [CrossRef]

55. Waked, A.; Afif, C.; Brioude, J.; Formenti, P.; Chevaillier, S.; El Haddad, I.; Doussin, J.-F.; Borbon, A.; Seigneur, C. Composition and Source Apportionment of Organic Aerosol in Beirut, Lebanon, During Winter 2012. Aerosol Sci. Technol. 2013, 47, 1258-1266. [CrossRef]

56. Waked, A.; Seigneur, C.; Couvidat, F.; Kim, Y.; Sartelet, K.; Afif, C.; Borbon, A.; Formenti, P.; Sauvage, S. Modeling air pollution in Lebanon: Evaluation at a suburban site in Beirut during summer. Atmos. Chem. Phys. 2013, 13, 5873-5886. [CrossRef]

57. Nazelle, A.; Fruin, S.; Westerdahl, D.; Mareinez, D.; Ripoll, A.; Kubesch, N.; Nieuwenhuijsen, M. A travel mode comparison of commuters' exposures to air pollutants in Barcelona. Atoms. Environ. 2012, 59, 151-159. [CrossRef]

58. Pérez, N.; Pey, J.; Cusack, M.; Reche, C.; Querol, X.; Alastuey, A.; Viana, M. Variability of Particle Number, Black Carbon, and $\mathrm{PM}_{10}, \mathrm{PM}_{2.5}$, and $\mathrm{PM}_{1}$ Levels and Speciation: Influence of Road Traffic Emissions on Urban Air Quality. Aerosol Sci. Technol. 2010, 44, 487-499. [CrossRef]

59. Okokon, E.O.; Yli-Tuomi, T.; Turunen, A.W.; Taimisto, P.; Pennanen, A.; Vouitsis, I.; Samaras, Z.; Voogt, M.; Keuken, M.; Lanki, T. Particulates and noise exposure during bicycle, bus and car commuting: A study in three European cities. Environ. Res. 2017, 154, 181-189. [CrossRef]

60. Knibbs, L.D.; Cole-Hunter, T.; Morawska, L. A review of commuter exposure to ultrafine particles and its health effects. Atoms. Environ. 2011, 45, 2611-2622. [CrossRef]

61. Knibbs, L.D.; de Dear, R.J.; Morawska, L. Effect of cabin ventilation rate on ultrafine particle exposure inside automobiles. Environ. Sci. Technol. 2010, 44, 3546-3551. [CrossRef]

62. Lim, S.; Dirks, K.N.; Salmond, J.A.; Xie, S. Determinants of spikes in ultrafine particle concentration whilst commuting by bus. Atoms. Environ. 2015, 112, 1-8. [CrossRef]

63. Both, A.F.; Westerdahl, D.; Fruin, S.; Haryanto, B.; Marshall, J.D. Exposure to carbon monoxide, fine particle mass, and ultrafine particle number in Jakarta, Indonesia: Effect of commute mode. Sci. Total Environ. 2013, 443, 965-972. [CrossRef] [PubMed]

64. Zhang, Q.; Fischer, H.J.; Weiss, R.E.; Zhu, Y. Ultrafine particle concentrations in and around idling school buses. Atoms. Environ. 2013, 69, 65-75. [CrossRef]

65. Liu, L.J.S.; Phuleria, H.C.; Webber, W.; Davey, M.; Lawson, D.R.; Ireson, R.G.; Zielinska, B.; Ondov, J.M.; Weaver, C.S.; Lapin, C.A.; et al. Quantification of self pollution from two diesel school buses using three independent methods. Atoms. Environ. 2010, 44, 3422-3431.

66. Zhang, Q.; Zhu, Y. Measurements of ultrafine particles and other vehicular pollutants inside school buses in South Texas. Atoms. Environ. 2010, 44, 253-261. [CrossRef]

67. Dingenen, R.A.; Raes, F.; Putaud, J.-P.; Baltensperger, U.; Charron, A.; Facchini, M.-C.; Decesari, S.; Fuzzi, S.; Gehrige, R.; Hansson, H.-C.; et al. A European aerosol phenomenology-1: Physical characteristics of particulate matter at kerbside, urban, rural and background sites in Europe. Atmos. Environ. 2004, 38, 2561-2577. [CrossRef]

68. Salma, I.; Borsos, T.; Weidinger, T.; Alato, P.; Hussein, T.; Dal Maso, M.; Kulmala, M. Production, growth and properties of ultrafine atmospheric aerosol particles in an urban environment. Atmos. Chem. Phys. 2011, 11, 1339-1353. [CrossRef]

69. Ruuskanen, J.; Tuch, T.; Brink, H.T.; Peters, A.; Khlystov, A.; Mirme, A.; Kos, G.P.A.; Brunekreef, B.; Wichmann, H.E.; Buzorius, G.; et al. Concentrations of ultrafine, fine and $\mathrm{PM}_{2.5}$ particles in three European cities. Atmos. Environ. 2001, 35, 3729-3738. [CrossRef]

70. Reche, C.; Querol, X.; Alastuey, A.; Viana, M.; Pey, J.; Moreno, T.; Rodriguez, S.; Gonzalez, Y.; Fernandez-Camacho, R.; de la Campa, A.M.S.; et al. New considerations for PM, Black Carbon and particle number concentration for air quality monitoring across different European cities. Atmos. Chem. Phys. 2011, 11, 6207-6227. [CrossRef]

71. Kumar, P.; Rivas, I.; Sachdeva, L. Exposure of in-pram babies to airborne particles during morning drop-in and afternoon pick-up of school children. Environ. Pollut. 2017, 224, 407-420. [CrossRef] 
72. Ragettli, M.S.; Corradi, E.; Braun-Fahrländer, C.; Schindler, C.; de Nazelle, A.; Jerrett, M.; Ducret-Stich, R.E.; Künzli, N.; Phuleria, H.C. Commuter exposure to ultrafine particles in different urban locations, transportation modes and routes. Atoms. Environ. 2013, 77, 376-384. [CrossRef]

73. Panis, I.L.; de Geus, B.; Vandenbulcke, G.; Willems, H.; Degraeuwe, B.; Bleux, N.; Mishra, V.; Thomas, I.; Meeusen, R. Exposure to particulate matter in traffic: A comparison of cyclists and car passengers. Atoms. Environ. 2010, 44, 2263-2270. [CrossRef]

74. Quiros, D.C.; Lee, E.S.; Wang, R.; Zhu, Y. Ultrafine particle exposures while walking, cycling, and driving along an urban residential roadway. Atoms. Environ. 2013, 73, 185-194. [CrossRef]

75. Ham, W.; Vijayan, A.; Schulte, N.; Herner, J.D. Commuter exposure to $\mathrm{PM}_{2.5}, \mathrm{BC}$, and UFP in six common transport microenvironments in Sacramento, California. Atoms. Environ. 2017, 167, 335-345. [CrossRef]

76. Boarnet, M.G.; Houston, D.; Edwards, R.; Princevac, M.; Ferguson, G.; Pan, H.; Bartolome, C. Fine particulate concentrations on sidewalks in five Southern California cities. Atoms. Environ. 2011,45, 4025-4033. [CrossRef]

77. Hankey, S.; Marshall, J.D. On-bicycle exposure to particulate air pollution: Particle number, black carbon, $\mathrm{PM}_{2.5}$, and particle size. Atoms. Environ. 2015, 122, 65-73. [CrossRef]

78. Pattinson, W.; Longley, I.; Kingham, S. Using mobile monitoring to visualise diurnal variation of traffic pollutants across two near-highway neighbourhoods. Atoms. Environ. 2014, 94, 782-792. [CrossRef]

79. Goel, R.; Gani, S.; Guttikunda, S.K.; Wilson, D.; Tiwari, G. On-road $\mathrm{PM}_{2.5}$ pollution exposure in multiple transport microenvironments in Delhi. Atoms. Environ. 2015, 123, 129-138. [CrossRef]

80. Apte, J.S.; Kirchstetter, T.W.; Reich, A.H.; Deshpande, S.J.; Kaushik, G.; Chel, A.; Marshall, J.D.; Nazaroff, W.W. Concentrations of fine, ultrafine, and black carbon particles in auto-rickshaws in New Delhi, India. Atoms. Environ. 2011, 45, 4470-4480. [CrossRef]

81. Qiu, Z.; Xu, X.; Song, J.; Luo, Y.; Zhao, R.; Zhou, B.X.W.; Hao, X.L.I.Y. Pedestrian exposure to traffic PM on different types of urban roads: A case study of Xi'an, China. Sustain. Cities Soc. 2017, 32, 475-485. [CrossRef]

82. Huang, J.; Deng, F.; Wu, S.; Guo, X. Comparisons of personal exposure to $\mathrm{PM}_{2.5}$ and $\mathrm{CO}$ by different commuting modes in Beijing, China. Sci. Total Environ. 2012, 425, 52-59. [CrossRef] [PubMed]

83. Betancourt, R.M.; Galvis, B.; Balachandran, S.; Ramos-Bonilla, J.P.; Sarmiento, O.L.; Gallo-Murcia, S.M.; Contreras, Y. Exposure to fine particulate, black carbon, and particle number concentration in transportation microenvironments. Atoms. Environ. 2017, 157, 135-145. [CrossRef]

84. Kulmala, M.; Kontkanen, J.; Junninen, H.; Lehtipalo, K.; Manninen, H.E.; Nieminen, T.; Petaja, T.; Sipila, M.; Schobesberger, S.; Rantala, P.; et al. Direct Observations of Atmospheric Aerosol Nucleation. Science 2013, 339, 943-946. [CrossRef] [PubMed]

85. Mølgaard, B.; Hussein, T.; Corander, J.; Hämeri, K. Forecasting Size-Fractionated Particle Number Concentrations in the Urban Atmosphere. Atmos. Environ. 2012, 46, 155-163. [CrossRef]

86. Mølgaard, B.; Birmili, W.; Clifford, S.; Massling, A.; Eleftheriadis, K.; Norman, M.; Vratolis, S.; Wehner, B.; Corander, J.; Hämeri, K.; et al. Evaluation of a statistical forecast model for size-fractionated urban particle number concentrations using data from five European cities. J. Aerosol Sci. 2013, 66, 96-110. [CrossRef]

87. Hussein, T.; Karppinen, A.; Kukkonen, J.; Härkonen, J.; Aalto, P.P.; Hämeri, K.; Kerminen, V.M.; Kulmala, M. Meteorological dependence of size fractionated number concentrations of urban aerosol particles. Atmos. Environ. 2006, 40, 1427-1440. [CrossRef]

88. Hussein, T.; Kukkonen, J.; Korhonen, H.; Pohjola, M.; Pirjola, L.; Wriath, D.; Härkönen, J.; Teinilä, K.; Koponen, I.K.; Karppinen, A.; et al. Evaluation and modeling of the size fractionated aerosol particle number concentration measurements nearby a major road in Helsinki-Part II: Aerosol measurements within the SAPPHIRE project. Atmos. Chem. Phys. 2007, 7, 4081-4094. [CrossRef]

89. Harrison, R.; Yin, J. Particulate matter in the atmosphere: Which particle properties are important for its effects on health? Sci. Total Environ. 2000, 249, 85-101. [CrossRef]

90. Harrison, R.M.; Jones, A.M.; Barrowcliffe, R. Field study of the influence of meteorological factors and traffic volumes upon suspended particle mass at urban roadside sites of differing geometries. Atmos. Environ. 2004, 38, 6361-6369. [CrossRef]

91. Charron, A.; Harrison, R.M. Primary particle formation from vehicle emissions during exhaust dilution in the roadside atmosphere. Atmos. Environ. 2003, 37, 4109-4119. [CrossRef]

92. Gidhagen, L.; Johansson, C.; Langner, J.; Olivares, G. Simulation of NOx and ultrafine particles in a street canyon in Stockholm, Sweden. Atmos. Environ. 2004, 38, 2029-2044. [CrossRef] 
93. Hosiokangas, J.; Vallius, M.; Ruuskanen, J.; Mirme, A.; Pekkanen, J. Resuspended dust episodes as an urban air-quality problem in subarctic regions. Scand. J. Work Environ. Health 2004, 30 (Suppl. 2), S28-S35.

94. Järvi, L.; Hannuniemi, H.; Hussein, T.; Junninen, H.; Aalto, P.P.; Hillamo, R.; Mäkelä, T.; Keronen, P.; Siivola, E.; Vesala, T;; et al. The urban measurement station SMEAR III: Continuous monitoring of air pollution and surface-atmosphere interactions in Helsinki, Finland. Boreal Environ. Res. 2009, 14 (Suppl. A), 86-109.

95. Krecl, P.; Ström, J.; Johansson, C. Diurnal variation of atmospheric aerosol during the wood combustion season in Northern Sweden. Atmos. Environ. 2008, 42, 4113-4125. [CrossRef]

96. Singh, A.K.; Rai, J.; Niwas, S. Variations of aerosols in relation to some meteorological parameters during different weather conditions. Atmósfera 2000, 13, 177-184.

(C) 2019 by the authors. Licensee MDPI, Basel, Switzerland. This article is an open access article distributed under the terms and conditions of the Creative Commons Attribution (CC BY) license (http://creativecommons.org/licenses/by/4.0/). 